\title{
Kratom Alkaloids: Interactions With Enzymes, Receptors, and Cellular Barriers
}

\author{
Nur Aziah Hanapi ${ }^{\dagger}$, Nelson Jeng-Yeou Chear ${ }^{\dagger}$, Juzaili Azizi ${ }^{\dagger}$ and Siti R. Yusof ${ }^{* \dagger}$ \\ Centre for Drug Research, Universiti Sains Malaysia, Minden, Malaysia
}

OPEN ACCESS

Edited by:

Kirsten Elin Smith,

National Institute on Drug Abuse Intramural Research Program,

United States

Reviewed by:

Walter Prozialeck,

Midwestern University, United States Hiroaki Shimada,

Kindai University, Japan

*Correspondence:

Siti R. Yusof

sryusof@usm.my

siti.yusof@ymail.com

${ }^{+}$These authors have contributed equally to this work and share first authorship

Specialty section:

This article was submitted to

Experimental Pharmacology and Drug

Discovery,

a section of the journal

Frontiers in Pharmacology

Received: 01 August 2021

Accepted: 26 October 2021

Published: 17 November 2021

Citation:

Hanapi NA, Chear NJ-Y, Azizi J and Yusof SR (2021) Kratom Alkaloids: Interactions With Enzymes, Receptors, and Cellular Barriers.

Front. Pharmacol. 12:751656. doi: 10.3389/fphar.2021.751656
Parallel to the growing use of kratom, there is a wealth of evidence from self-report, preclinical, and early clinical studies on therapeutic benefits of its alkaloids in particular for treating pain, managing substance use disorder, and coping with emotional or mental health conditions. On the other hand, there are also reports on potential health risks concerning kratom use. These two aspects are often discussed in reviews on kratom. Here, we aim to highlight specific areas that are of importance to give insights into the mechanistic of kratom alkaloids pharmacological actions. This includes their interactions with drug-metabolizing enzymes and predictions of clinical drug-drug interactions, receptor-binding properties, interactions with cellular barriers in regards to barrier permeability, involvement of membrane transporters, and alteration of barrier function when exposed to the alkaloids.

Keywords: receptor-binding, mitragynine, Mitragyna speciosa, metabolism, kratom, alkaloids, drug-drug interactions, barrier permeability

\section{INTRODUCTION}

Kratom (Mitragyna speciosa Korth.) use in the traditional settings in Southeast Asian countries particularly Malaysia and Thailand to treat minor ailments and to increase work endurance among manual laborers is not new. Reports on the use of kratom as a substitute for opium in Malaya have been published as early as in the 1930s (Burkill and Haniff, 1930; Burkill, 1935). Now, kratom use has spread to the West particularly in the United States of which kratom products are widely marketed online (Williams and Nikitin, 2020). Reasons for kratom use in the States include to self-treat acute and chronic pain, to reduce or abstain from using non-prescription opioids and/or heroin, and to a lesser extent as a substitute for the drugs, and to cope with emotional or mental health conditions such as anxiety, depression and post-traumatic stress disorder (Grundmann, 2017; Smith and Lawson 2017; Smith et al., 2021). The increasing use of kratom which is no longer limited to Southeast Asian countries has sparked many interests within the scientific community to investigate the therapeutic potential of the plant and possible health risks. A breadth of evidence is available on pharmacological actions of kratom preparations and alkaloids, primarily central actions of mitragynine and 7-hydroxymitragynine. Apart from the two most studied alkaloids, there is a growing number of other alkaloids being reported and to date, approximately 45 alkaloids were identified in kratom (Ramanathan et al., 2021). Chemical structures of kratom alkaloids which are discussed in the later sections of this review are shown in Figure 1. Findings from preclinical studies, for example, antinociceptive activity to some extent corroborated with data from self-report studies of which among the reasons for kratom use is to manage pain, further supported by the recent randomized controlled study in humans (Vicknasingam et al., 2020). This also seems to be the case for use of kratom to alleviate opioid withdrawal (Hassan et al., 2020) and to relieve anxiety (Hazim 


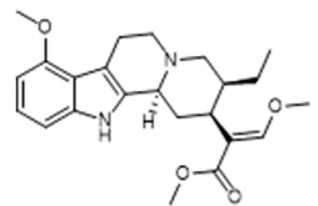

(1)<smiles>C=C[C@H]1CN2CCc3c([nH]c4cccc(OC)c34)[C@H]2C[C@H]1/C(=C\OC)C(=O)OC</smiles>

(6)

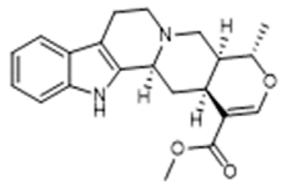

(11)

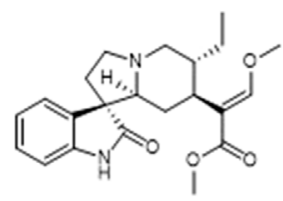

(16)

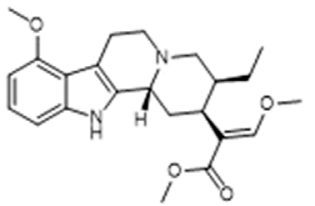

(2)

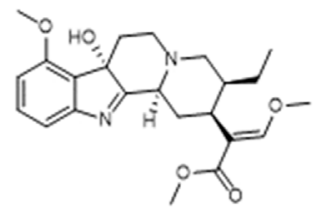

(7)

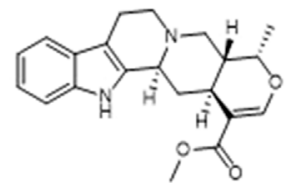

(12)

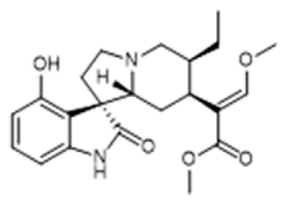

(17)

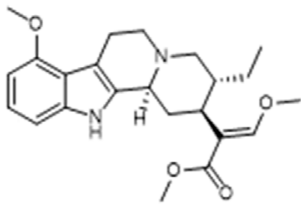

(3)

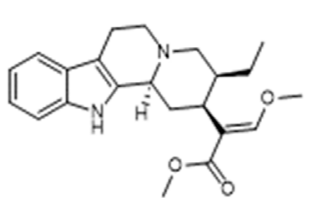

(8)

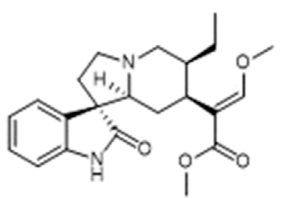

(13)

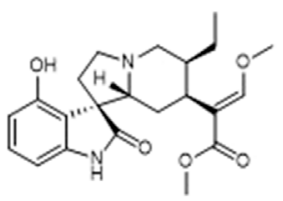

(18)

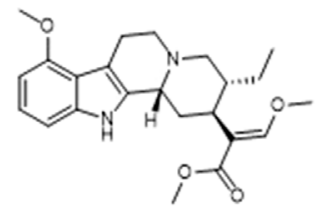

(4)

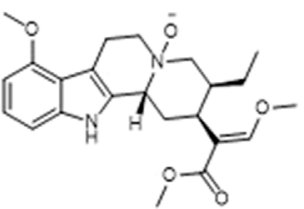

(9)

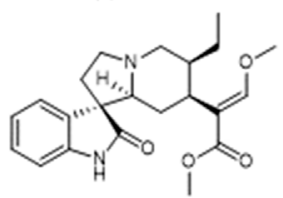

(14)

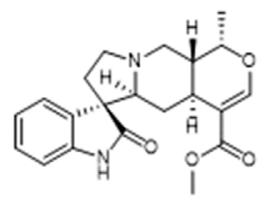

(19)

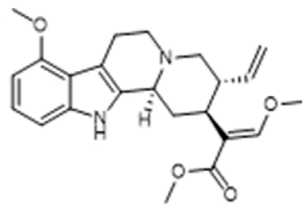

(5)<smiles>CCC1CN(C)CCC2=C1NC1=CC=CC(OC)=C2C1</smiles>

(10)

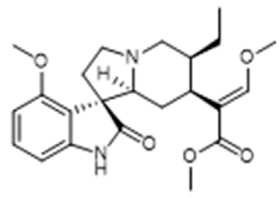

(15)

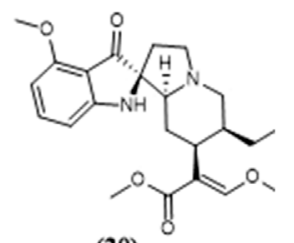

(20)

FIGURE 1 | Chemical structures of selected kratom alkaloids-(1) mitragynine, (2) speciociliatine, (3) speciogynine, (4) mitraciliatine, (5) paynantheine, (6) isopaynantheine, (7) 7-hydroxymitragynine, (8) corynantheidine, (9) speciociliatine n-oxide, (10) mitragynine n-oxide, (11) tetrahydroalstonine, (12) ajmalicine, (13) corynoxine, (14) corynoxine $\mathrm{B},(\mathbf{1 5})$ mitragynine oxindole $\mathrm{B},(\mathbf{1 6})$ isorynchophylline, (17) isospeciofoline, (18) speciofoline, (19) mitraphylline, (20) mitragynine pseudoindoxyl.

et al., 2014). Further investigations at the cellular and molecular level aid to gain an understanding of the mechanistic of kratom alkaloids actions.

Here, we highlight physiological interactions of kratom alkaloids focusing on interactions with enzymes, receptors, and cellular barriers. These are emerging areas of research concerning kratom alkaloids of which are of significant importance in determining potential development as therapeutics.

\section{INTERACTIONS WITH ENZYMES}

\subsection{Metabolism of Kratom Alkaloids}

Metabolism facilitates the elimination of drugs from animals and humans through the conversion of the drugs to more watersoluble metabolites. There are two phases of drug metabolism i.e., phase I and phase II. Phase I metabolism includes hydrolysis, oxidation, and reduction reactions which are mainly catalyzed by various drug-metabolizing enzymes (DMEs). Phase II consists of a conjugation reaction involving glucuronidation and sulfation (Shapiro and Shear, 2001).
To date, limited data are available concerning the metabolic pathways of kratom alkaloids and the involvement of various DMEs in the clearance of the alkaloids. Data from analyses of samples collected from rats and humans revealed that kratom alkaloids including mitragynine, speciogynine, paynantheine, speciociliatine, mitraciliatine, and isopaynantheine were extensively metabolized to multiple phase I and phase II metabolites. Phase I metabolism of the alkaloids involved hydrolysis of the methyl ester of the acrylic acid group at $\mathrm{C}$ $16, O$-demethylation of the methoxy group at C-9 and C-17 positions, followed by oxidation to carboxylic acid or reduction to alcohol (Philipp et al., 2009; Philipp et al., 2010a; Philipp et al., 2010b; Philipp et al., 2011a; Philipp et al., 2011b). Following the phase I metabolism, some metabolites underwent phase II metabolism to produce glucuronide and sulfate conjugates (Phillip et al., 2009). The phase I and phase II metabolites of the alkaloids are tabulated in Table 1. In parallel to the list of metabolites, the proposed metabolic pathways for the alkaloids are illustrated in Figures 2-7.

Kamble et al. (2019) characterized the metabolic profile of mitragynine against various cytochrome P450 (CYP)containing systems including human liver microsomes 
TABLE 1 | Phase I and II metabolites of kratom alkaloids in rat and human urine samples.

\begin{tabular}{|c|c|c|c|c|}
\hline \multirow[t]{2}{*}{ Alkaloid } & \multicolumn{2}{|c|}{ Phase I metabolites } & \multicolumn{2}{|c|}{ Phase II metabolites } \\
\hline & Rat urine & Human urine & Rat urine & Human urine \\
\hline \multirow[t]{11}{*}{$M^{a}$} & 1) 9-O-demethyl MG & 1) 9-O-demethyl MG & Glucuronides of: & Glucuronides of: \\
\hline & 2) 16-carboxy MG & 2) 16-carboxy MG & 1) 9-O-demethyl MG & 1) 9-O-demethyl MG \\
\hline & 3) 9-O-demethyl-16-carboxy MG & 3) 17-O-demethyl-16,17-dihydro MG & 2) 16-carboxy MG & 2) 16-carboxy MG \\
\hline & 4) 17-O-demethyl-16,17-dihydro MG & 4) 17-carboxy-16,17-dihydro MG & 3) 9-O-demethyl-16-carboxy MG & 3) 17-O-demethyl-16,17- \\
\hline & 5) 9,17-O-bisdemethyl-16,17-dihydro MG & & 4) 9,17-O-bisdemethyl-16,17- & dihydro MG \\
\hline & 6) 17-carboxy-16,17-dihydro MG & & dihydro MG & \\
\hline & $\begin{array}{l}\text { 7) 9-O-demethyl-17-carboxy-16,17- } \\
\text { dihydro MG }\end{array}$ & & & \\
\hline & & & Sulfate of: & Sulfates of: \\
\hline & & & 1) 9-O-demethyl-16-carboxy MG & 1) 9-O-demethyl MG \\
\hline & & & & 2) 9-O-demethyl-16-carboxy MG \\
\hline & & & & $\begin{array}{l}\text { 3) 9,17-O-bisdemethyl-16,17- } \\
\text { dihydro MG }\end{array}$ \\
\hline \multirow[t]{10}{*}{ PAY } & 1) 9-O-demethyl PAY & 1) 9-O-demethyl PAY & Glucuronides of: & Glucuronides of: \\
\hline & 2) 16-carboxy PAY & 2) 16-carboxy PAY & 1) 9-O-demethyl PAY & 1) 9-O-demethyl PAY \\
\hline & 3) 9-O-demethyl-16-carboxy PAY & 3) 17-carboxy-16,17-dihydro PAY & 2) 16-carboxy PAY & 2) 16-carboxy PAY \\
\hline & 4) 17-O-demethyl-16,17-dihydro PAY & & 3) 9-O-demethyl-16-carboxy PAY & \\
\hline & 5) 9,17-O-bisdemethyl-16,17-dihydro PAY & & 4) 17-O-demethyl-16,17- & \\
\hline & 6) 17-carboxy-16,17-dihydro PAY & & dihydro PAY & \\
\hline & $\begin{array}{l}\text { 7) 9-O-demethyl-17-carboxy-16,17- } \\
\text { dihydro PAY }\end{array}$ & & $\begin{array}{l}\text { 5) 9,17-O-bisdemethyl-16,17- } \\
\text { dihydro PAY }\end{array}$ & \\
\hline & 8) 17-O-demethyl PAY & & 6) 17-O-demethyl PAY & \\
\hline & 9) 9,17-O-bisdemethyl PAY & & 7) 9,17-O-bisdemethyl PAY & \\
\hline & & & $\begin{array}{l}\text { Sulfate of: } \\
\text { 1) 9,17-O-bisdemethyl-16,17- } \\
\text { dihydro PAY }\end{array}$ & $\begin{array}{l}\text { Sulfate of: } \\
\text { 1) 9-O-demethyl PAY }\end{array}$ \\
\hline \multirow[t]{12}{*}{$S G^{c}$} & 1) 9-O-demethyl SG & 1) 9-O-demethyl SG & Glucuronides of: & Glucuronides of: \\
\hline & 2) 16-carboxy SG & 2) 16-carboxy SG & 1) 9-O-demethyl SG & 1) 9-O-demethyl SG \\
\hline & 3) 9-O-demethyl-16-carboxy SG & 3) 17-carboxy-16,17-dihydro SG & 2) 16-carboxy SG & 2) 16-carboxy SG \\
\hline & 4) 17-O-demethyl-16,17-dihydro SG & & 3) 9-O-demethyl-16-carboxy SG & \\
\hline & 5) 9,17-O-bisdemethyl-16,17-dihydro SG & & 4) 17-O-demethyl-16,17- & \\
\hline & 6) 17-carboxy-16,17-dihydro SG & & dihydro SG & \\
\hline & 7) 9-O-demethyl-17-carboxy-16,17- & & 5) 9,17-O-bisdemethyl-16,17- & \\
\hline & dihydro SG & & dihydro SG & \\
\hline & 8) 17-O-demethyl SG & & 6) 17-O-demethyl SG & \\
\hline & 9) 9,17-O-bisdemethyl SG & & 7) 9,17-O-bisdemethyl SG & \\
\hline & & & Sulfate of: & Sulfate of \\
\hline & & & $\begin{array}{l}\text { 1) 9,17-O-bisdemethyl-16,17- } \\
\text { dihydro SG }\end{array}$ & 1) 9-O-demethyl SG \\
\hline \multirow[t]{9}{*}{$S C^{d}$} & 1) 9-O-demethyl SC & 1) 9-O-demethyl SC & Glucuronides of: & Glucuronides of: \\
\hline & 2) 16-carboxy SC & 2) 16-carboxy SC & 1) 9-O-demethyl SC & 1) 9-O-demethyl SC \\
\hline & 3) 9-O-demethyl-16-carboxy SC & 3) 9-O-demethyl-16-carboxy SC & 2) 16-carboxy SC & 2) 16-carboxy SC \\
\hline & 4) 17-O-demethyl-16,17-dihydro SC & & 3) 9-O-demethyl-16-carboxy SC & 3) 17-O-demethyl-16,17- \\
\hline & 5) 9,17-O-bisdemethyl-16,17-dihydro SC & & 4) 17-O-demethyl-16,17- & dihydro SC \\
\hline & 6) 17-carboxy-16,17-dihydro SC & & dihydro SC & \\
\hline & $\begin{array}{l}\text { 7) 9-O-demethyl-17-carboxy-16,17- } \\
\text { dihydro SC }\end{array}$ & & $\begin{array}{l}\text { 5) 9,17-O-bisdemethyl-16,17- } \\
\text { dihydro SC }\end{array}$ & \\
\hline & 8) $17-0$-demethyl SC & & 6) 9,17-O-bisdemethyl SC & \\
\hline & 9) 9,17-O-bisdemethyl SC & & & \\
\hline \multirow[t]{9}{*}{$\mathrm{MC}^{\mathrm{e}}$} & 1) 9-O-demethyl MC & 1) 9-O-demethyl MC & Glucuronides of & Glucuronide of: \\
\hline & 2) 16-carboxy MC & & 1) 9 -O-demethyl MC & 1) 9 -O-demethyl MC \\
\hline & 3) 9-O-demethyl-16-carboxy MC & & 2) 16-carboxy MC & \\
\hline & 4) 17-O-demethyl-16,17-dihydro MC & & 3) 9-O-demethyl-16-carboxy MC & \\
\hline & 5) 9,17-O-bisdemethyl-16,17-dihydro MC & & 4) 17-O-demethyl-16,17- & \\
\hline & 6) 17-carboxy-16,17- dihydro MC & & dihydro MC & \\
\hline & $\begin{array}{l}\text { 7) 9-O-demethyl-17-carboxy-16,17- } \\
\text { dihydro MC }\end{array}$ & & $\begin{array}{l}\text { 5) 9,17-O-bisdemethyl-16,17- } \\
\text { dihydro MC }\end{array}$ & \\
\hline & $\begin{array}{l}\text { dinydro } \mathrm{MIC} \\
\text { 8) 17-O-demethyl MC }\end{array}$ & & 6) 17-O-demethyl MC & \\
\hline & 9) 9,17-O-bisdemethyl MC & & 7) 9,17-O-bisdemethyl MC & \\
\hline
\end{tabular}


TABLE 1 | (Continued) Phase I and II metabolites of kratom alkaloids in rat and human urine samples.

\begin{tabular}{|c|c|c|c|c|}
\hline \multirow[t]{2}{*}{ Alkaloid } & \multicolumn{2}{|c|}{ Phase I metabolites } & \multicolumn{2}{|c|}{ Phase II metabolites } \\
\hline & Rat urine & Human urine & Rat urine & Human urine \\
\hline ISO- & 1) 9-O-demethyl ISO-PAY & 1) 9-O-demethyl ISO-PAY & Glucuronides of: & \\
\hline \multirow[t]{10}{*}{ PAY } & 2) 16-carboxy ISO-PAY & 2) 17-carboxy-16,17-dihydro ISO-PAY & 1) 9-O-demethyl ISO-PAY & \\
\hline & 3) 9-O-demethyl-16-carboxy ISO-PAY & & 2) 16-carboxy ISO-PAY & \\
\hline & 4) 17-O-demethyl-16,17-dihydro ISO-PAY & & 3) 17-O-demethyl-16,17-dihydro & \\
\hline & 5) 9,17-O-bisdemethyl-16,17-dihydro & & ISO-PAY & \\
\hline & ISO-PAY & & 4) 17-O-demethyl ISO-PAY & \\
\hline & 6) 17-carboxy-16,17-dihydro ISO-PAY & & & \\
\hline & 7) 9-O-demethyl-17-carboxy-16,17- & & & \\
\hline & dihydro ISO-PAY & & & \\
\hline & 8) 17-O-demethyl ISO-PAY & & & \\
\hline & 9) 9,17-O-bisdemethyl ISO-PAY & & & \\
\hline
\end{tabular}

MG, mitragynine; PAY, paynantheine; SG, speciogynine; SC, speciociliatine; MC, mitraciliatine; ISO-PAY, isopaynantheine.

${ }^{a}$ Phillip et al.(2009):

${ }^{b}$ Phillip et al. (2010a);

${ }^{c}$ Phillip et al. (2010b);

${ }^{d}$ Phillip et al. (2011a);

${ }^{e}$ Phillip et al. (2011b).

(HLM), human liver S9 (HLS9), and recombinant CYP enzymes. In the HLM system, four oxidative species including 7-hydroxymitragynine and one $O$-demethylated metabolite i.e., 9-O-demethylmitragynine were detected as the prevalent metabolites of mitragynine, in accord with Basiliere and Kerrigan (2020a). None of the mitragynine phase I metabolites was discovered to be conjugated with glutathione. The metabolite profiling of mitragynine was comparable in HLM and HLS9, where both systems demonstrated a minor metabolic pathway. On the other hand, CYP3A4 was discovered as the major CYP isoform responsible for the metabolism of mitragynine with small or negligible contributions from CYP2C9, 2C19, and 2D6. The data on metabolic pathways of mitragynine via recombinant CYP enzymes were further evaluated against a series of multiple isoforms of 1A2, 2B6, 2C8, 2C9, 2C18, 2C19, 2D6, and 3A4 (Basiliere and Kerrigan, 2020b). Only 2C18, $2 \mathrm{C} 19,2 \mathrm{D} 6$, and $3 \mathrm{~A} 4$ isoforms displayed metabolic activities among the tested enzymes. The results indicate that 9-Odemethylmitragynine was the most abundant metabolite produced by $\mathrm{CYP} 2 \mathrm{C} 19,2 \mathrm{D} 6$, and $3 \mathrm{~A} 4$, while 9-Odemethyl-16-carboxymitragynine was the least prevalent metabolite hydrolyzed by 2C19. 16-Carboxymitragynine was produced by CYP2C19 and 2D6 while 7hydroxymitragynine was only produced by CYP3A4. Although data from Kamble et al. (2019) showed negligible metabolic activity expressed by CYP2C19 and 2D6, the data reported by Basiliere and Kerrigan (2020b) indicate that both isoforms were capable of metabolizing mitragynine to several important metabolites.

\subsection{Potential Drug-Drug Interactions}

This section deals with interactions of mitragynine and related alkaloids in modulating enzymes especially for enzymes that pose clinical importance. As the DMEs are the primary route of drug clearance in the human body ( $\mathrm{Di}, 2014)$, modulation of the expression or function of DMEs through inhibition or induction by one or more chemicals that affect the metabolism of clinical drugs may lead to toxic effects or lack of clinical efficacy (Food and Drug Administration Center for Drug Evaluation and Research, 2020). The serious impact of DMEs modulation by other chemicals leads to the universal use of the term drug-drug interaction (DDI) to specifically refer to this type of interaction. DDI is often the primary obstacle in drug discovery and development and causes many clinically approved drugs to be withdrawn from the market (Wienkers and Heath, 2005). DDI can be recognized earlier in the preclinical phase by good experimental designs and by following guidelines provided by regulating agencies such as the U.S. Food and Drug Administration (FDA) (Food and Drug Administration Center for Drug Evaluation and Research, 2020) and European Medicines Agency (European Medicines Agency, 2012). Interactions of mitragynine with enzymes other than DMEs have also been reported. However, studies on these enzymes were very limited, with just acetylcholinesterase (Innok et al., 2021) and cyclooxygenase (Utar et al., 2011) being evaluated. Findings from these studies were less clinically relevant as the experiments were performed using enzymes from non-human sources i.e., electric eel for acetylcholinesterase, and rodent macrophage cell lines for cyclooxygenase, or the inhibition data showed mitragynine concentration that is hardly attained in human plasma, for example, $\mathrm{IC}_{50}$ of $264 \mu \mathrm{M}$ for acetylcholinesterase.

It is obvious from the preceding section that mitragynine and other related alkaloids are substrates for multiple CYP isoforms and hence may interfere with metabolisms of clinical drugs. Preclinical research on mitragynine and related alkaloids on DDI is limited but has been gaining attention within the last 10 years (Hanapi et al., 2013; Lim et al., 2013; Kamble et al., 2020; Todd et al., 2020; Tanna et al., 2021). Here, the focus is on the effect of mitragynine and related alkaloids on DMEs from in vitro preclinical research, and their utility to predict clinical DDI. Only studies on human DMEs that make clinical prediction possible were included in this review (Table 2). 


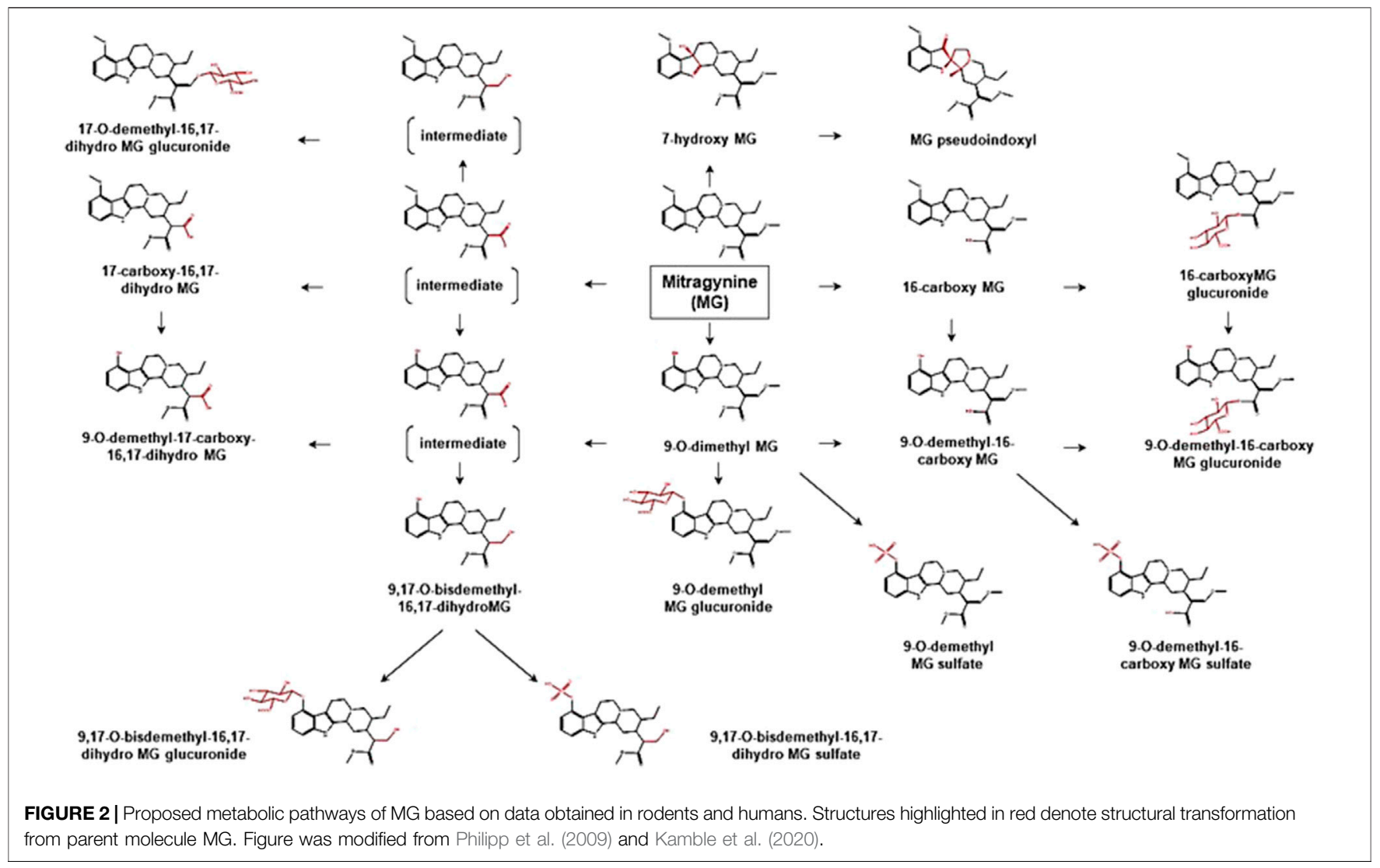

The CYPs 1A2, 2C9, 2C19, 2D6, 2E1, and 3A4 isoforms are the major phase I DMEs responsible for the metabolism of over $90 \%$ of commercially marketed drugs (Lynch and Price, 2007; Bibi, 2008). The first study of mitragynine interactions with CYPs by Hanapi et al. (2013) set precedence to the subsequent studies that revealed more detailed information on the mechanisms and strength of DDI. The inhibitory constant parameter such as $\mathrm{IC}_{50}$ and $\mathrm{K}_{\mathrm{i}}$ gathered from these studies were useful to support the prediction of potential clinical DDI through a static mechanistic model or physiologically based pharmacokinetic modeling (Obach et al., 2006; Templeton et al., 2016; Tod et al., 2016). For example, using the static mechanistic model, a ratio of the area under the plasma versus concentration-time curve (AUCR) for known CYP isoform substrate in the presence to absence of inhibitor could be estimated. An AUCR > 1.25 may suggest potential clinical DDI (Food and Drug Administration Center for Drug Evaluation and Research, 2020). The cut-off point of $\mathrm{K}_{\mathrm{i}}<12 \mu \mathrm{M}$ to group mitragynine and other alkaloids as a potential clinical inhibitor of DMEs in this review was based on the guidelines provided by Tanna et al. (2021). Mitragynine $\mathrm{K}_{\mathrm{i}}$ value from DMEs inhibition study $<12 \mu \mathrm{M}$ denote potential clinical relevance of CYP inhibition, determined relative to the highest mitragynine concentration quantified from autopsy blood samples of kratom-related death (Gershman et al., 2019; Tanna et al., 2021). For enzyme induction, a recent FDA guideline was used to classify CYP induction as potentially clinically significant (Food and Drug Administration Center for Drug Evaluation and Research, 2020). According to the guideline, a drug is interpreted as an inducer if the fold change of CYP mRNA expression relative to the vehicle control is $\geq 2$-fold at the expected hepatic concentrations of the drug and/or if the increase is $>20 \%$ of the response of the positive control in vitro cell-based assay.

Mitragynine and other alkaloids inhibited the $O$-deethylation reaction of CYP1A2 substrate phenacetin with a $K_{i}$ value greater than the concentration that could be obtained in human plasma (Kamble et al., 2020). However, a study with human liver cancer cell line HepG2 showed the imminent potential of CYP1A2 induction by mitragynine (Lim et al., 2013). The mRNA expression for CYP1A2 when exposed to $10 \mu \mathrm{M}$ mitragynine exceeded 2 -fold relative to negative control and the increase was approximately $28 \%$ of the response of the CYP1A2 known inducer omeprazole in the cell-based assay ( $\mathrm{Lim}$ et al., 2013). For the CYP2C subfamily, mitragynine and related alkaloids did not appreciably inhibit CYP2C8 and CYP2C9 (Kamble et al., 2020). However, mitragynine and speciociliatine inhibited CYP2C19 catalyzed S-mephenytoin hydroxylation with $\mathrm{IC}_{50}$ values of 10.6 and $8 \mu \mathrm{M}$ respectively (Kamble et al., 2020). Although the study by Kamble et al. (2020) did not measure $K_{i}$ for mitragynine and speciociliatine, estimation through Cheng-Prusoff equation (Yung-Chi and Prusoff, 1973; Haupt et al., 2015) for 


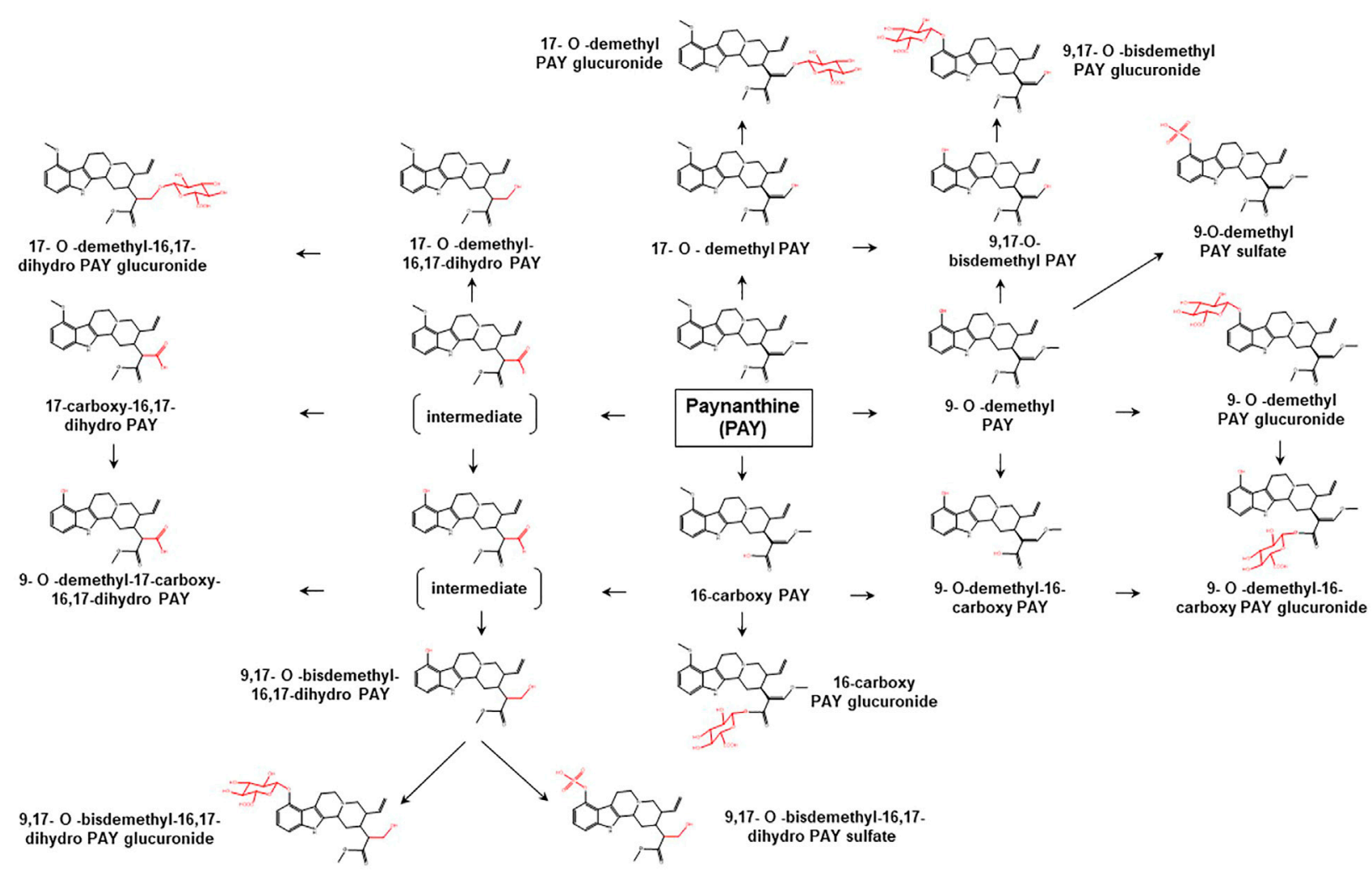

FIGURE 3 | Proposed metabolic pathways of PAY based on data obtained in rodents and humans. Structures highlighted in red denote structural transformation from parent molecule PAY. Figure was modified from Philipp et al. (2010a).

competitive inhibitor $\left(\mathrm{K}_{\mathrm{i}}=\mathrm{IC}_{50} / 2\right)$ may suggest potential clinical DDI between mitragynine $\left(\mathrm{K}_{\mathrm{i}} \sim 5 \mu \mathrm{M}\right)$ and speciociliatine $\left(\mathrm{K}_{\mathrm{i}} \sim 4 \mu \mathrm{M}\right)$ for drugs mainly metabolized by CYP2C19. Speciociliatine was the third $[0.29 \%(w / w)]$ major alkaloid after mitragynine $[3.8 \%(\mathrm{w} / \mathrm{w})]$ in the Malaysian strain of kratom juice preparation and may significantly reach the $\mathrm{K}_{\mathrm{i}}$ concentration in chronic kratom users assuming the intestinal absorption similar to mitragynine (Singh et al., 2020a).

Mitragynine has been repeatedly shown in different in vitro studies to potently inhibit CYP2D6 with $\mathrm{K}_{\mathrm{i}}$ values ranging from 1.1 to $13 \mu \mathrm{M}$ (Hanapi et al., 2013; Kamble et al., 2020; Todd et al., 2020; Tanna et al., 2021). Using the static mechanistic model, Tanna et al. (2021) revealed that kratom preparation sold in the U.S. market could cause significant DDI with drugs primarily metabolized by CYP2D6 if more than $9 \mathrm{~g}$ kratom extract containing $83 \mathrm{mg}$ mitragynine (Todd et al., 2020) was taken with AUCR $>1.25$. Based on this finding, the reported daily intake average i.e., 2.7 glasses of traditionally prepared kratom juice among chronic kratom users in Malaysia (Singh et al., 2020a) is sufficient to cause significant DDI with dextromethorphan (AUCR 1.4). Mitragynine did not appear to have a significant effect on the mRNA expression of CYP2D6. Although there was a substantial protein induction based on a qualitative technique for protein expression, the fold-induction did not qualify mitragynine as a clinically relevant CYP2D6 inducer (Lim et al., 2013).
Mitragynine was initially thought not to effectively inhibit the CYP3A4 isoform in a bioluminescent experiment with an IC $_{50}$ of $41.32 \mu \mathrm{M}$ (Hanapi et al., 2013). Subsequent studies with HLM support the previous data but with a much lower $\mathrm{IC}_{50}$ of $<20 \mu \mathrm{M}$ when FDA recommended CYP3A4 probe substrate midazolam was used (Kamble et al., 2020; Tanna et al., 2021). Mitragynine also appears to inhibit CYP3A4 catalyzed midazolam hydroxylation in human intestinal microsomes (HIM) with $\mathrm{IC}_{50}=21.9 \mu \mathrm{M}$ (Tanna et al., 2021). Interestingly, mitragynine $\mathrm{IC}_{50}$ for CYP3A4 reduced substantially to $2.6 \mu \mathrm{M}$ (HLM) and $3.2 \mu \mathrm{M}$ (HIM) in a timedependent inhibition experimental design (Tanna et al., 2021). The time-dependent inhibition observed from the study highlighted a mechanism-based inhibition that was irreversible and more potent for CYP3A4. In this type of inhibition, a product of mitragynine metabolism is covalently bound to the CYP3A4 active site instead of being released, which rendered the enzyme unavailable for other reactions (Deodhar et al., 2020). This observation was frequently missed in classical $\mathrm{IC}_{50}$ assays as the study design limit sufficient formation of active metabolites to form and deactivate the CYP. The impact of this finding is huge as roughly $40 \%$ of clinical drugs are substrates for CYP3A4 metabolism (Schaffenburg et al., 2021). The static mechanistic model demonstrated that as little as $2 \mathrm{~g}$ kratom powder containing $21 \mathrm{mg}$ mitragynine (Todd et al., 


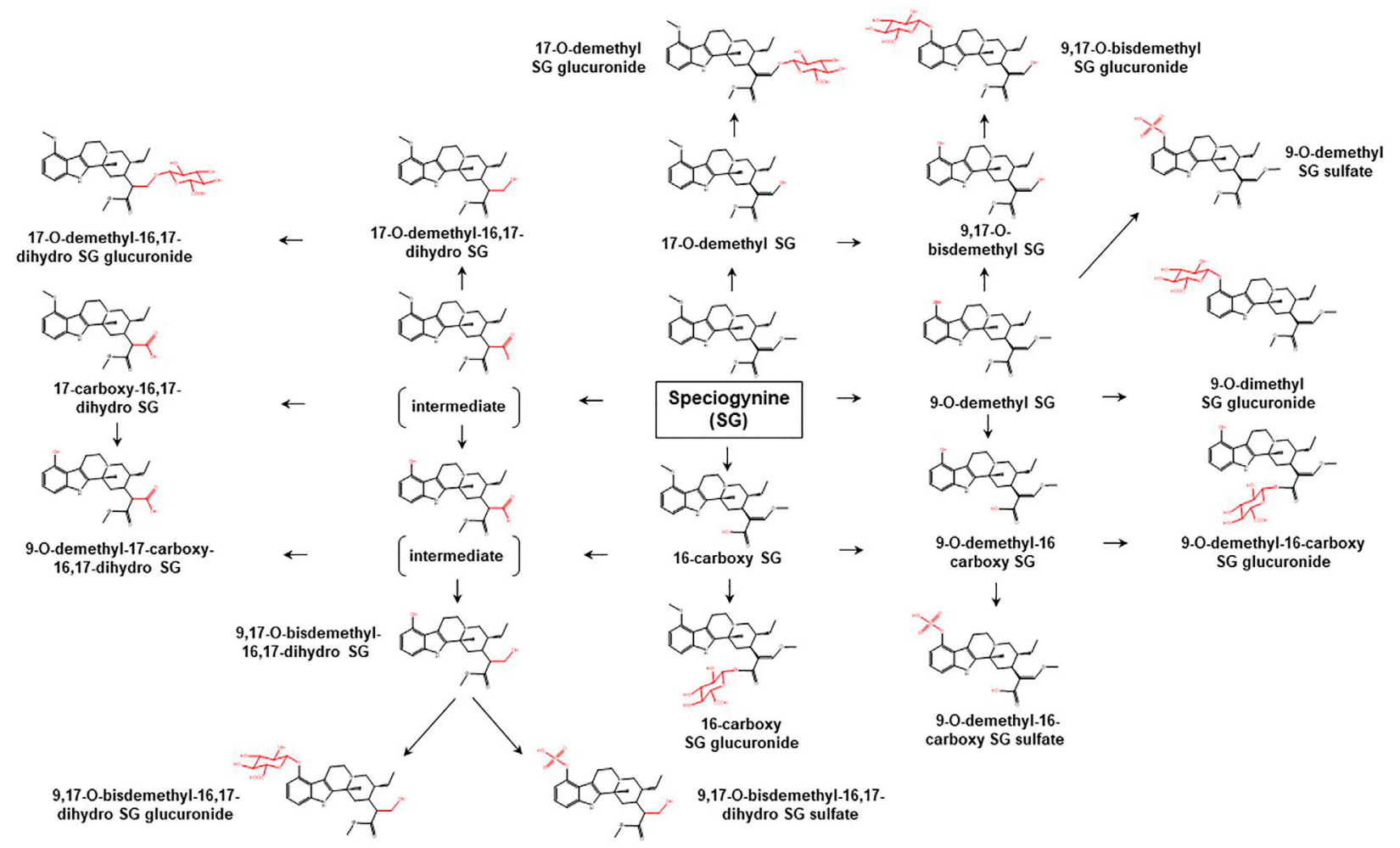

FIGURE 4 | Proposed metabolic pathways of SG based on data obtained in rodents and humans. Structures highlighted in red denote structural transformation from parent molecule SG. Figure was modified from Philipp et al. (2010b).

2020) will precipitate DDI with CYP3A4 substrate midazolam $($ AUCR $=5.7)$ (Tanna et al., 2021). Similarly, about half-glass $(\sim 150 \mathrm{ml})$ of traditionally prepared Malaysian kratom juice daily (Singh et al., 2020a) would be estimated to progressively increase the plasma level of midazolam by $\sim 6$ fold. The influence of mitragynine on midazolam clearance would be substantially greater among chronic kratom users in Malaysia with AUCR > 12. On the other hand, the effects of mitragynine on the CYP3A4 mRNA, protein, and enzymatic activity in HepG2 cells were all below the criteria to suggest a significant in vitro induction effect (Lim et al., 2013).

\section{INTERACTIONS OF KRATOM ALKALOIDS WITH CENTRAL NERVOUS SYSTEM RECEPTORS}

The effects of kratom alkaloids on central nervous system (CNS) receptors have been extensively studied in vitro and in vivo assays. In vitro radioligand binding studies revealed that kratom alkaloids interact with opioid $\mu, \delta, \kappa$ subtypes, and non-opioid receptors including alpha-1A, alpha-2A, 5-HT1A, 5-HT2A, D1, and D2 (Takayama et al., 2002; Boyer et al., 2008; Kruegel et al., 2016; Ellis et al., 2020; Obeng et al., 2020; Chear et al., 2021; Obeng et al., 2021). In vivo studies demonstrated that kratom alkaloids exert central analgesic, anti-anxiety, anti-drug addiction, and antipsychotic effects primarily through activation of central opioidergic, adrenergic, serotoninergic, and dopaminergic neurotransmission systems (Matsumoto et al., 1996a; Matsumoto et al., 1996b; Matsumoto et al., 1997; Takayama et al., 2002; Hazim et al., 2014; Vijeepallam et al., 2016; Foss et al., 2020; Obeng et al., 2020; Chear et al., 2021; Obeng et al., 2021). To better understand the CNS pharmacological targets of kratom alkaloids, this section is structured as follows: opioid receptors and non-opioid receptors (adrenergic, serotonin, and dopamine receptors).

\subsection{Opioid Receptors}

Kratom extracts (alcoholic, water, and alkaloid-enriched extracts) and the main alkaloid i.e., mitragynine demonstrated significant central analgesic activity in rodents and humans, and were fully antagonized by the non-selective opioid antagonists such as naloxone or naltrexone in most cases (Matsumoto et al., 1996a; Shaik Mossadeq et al., 2009; Sabetghadam et al., 2010; Carpenter et al., 2016; Vicknasingam et al., 2020). These suggest that the central analgesic effects of kratom and mitragynine are primarily mediated by opioid receptors (Ramanathan et al., 2021). Takayama et al. (2002) were the first to report on the interaction of mitragynine and its related indole alkaloids, 7 hydroxymitragynine, corynantheidine, and speciociliatine with $\mu$-opioid receptors derived from guinea pig (Takayama et al., 2002). The opioid agonistic activity of 


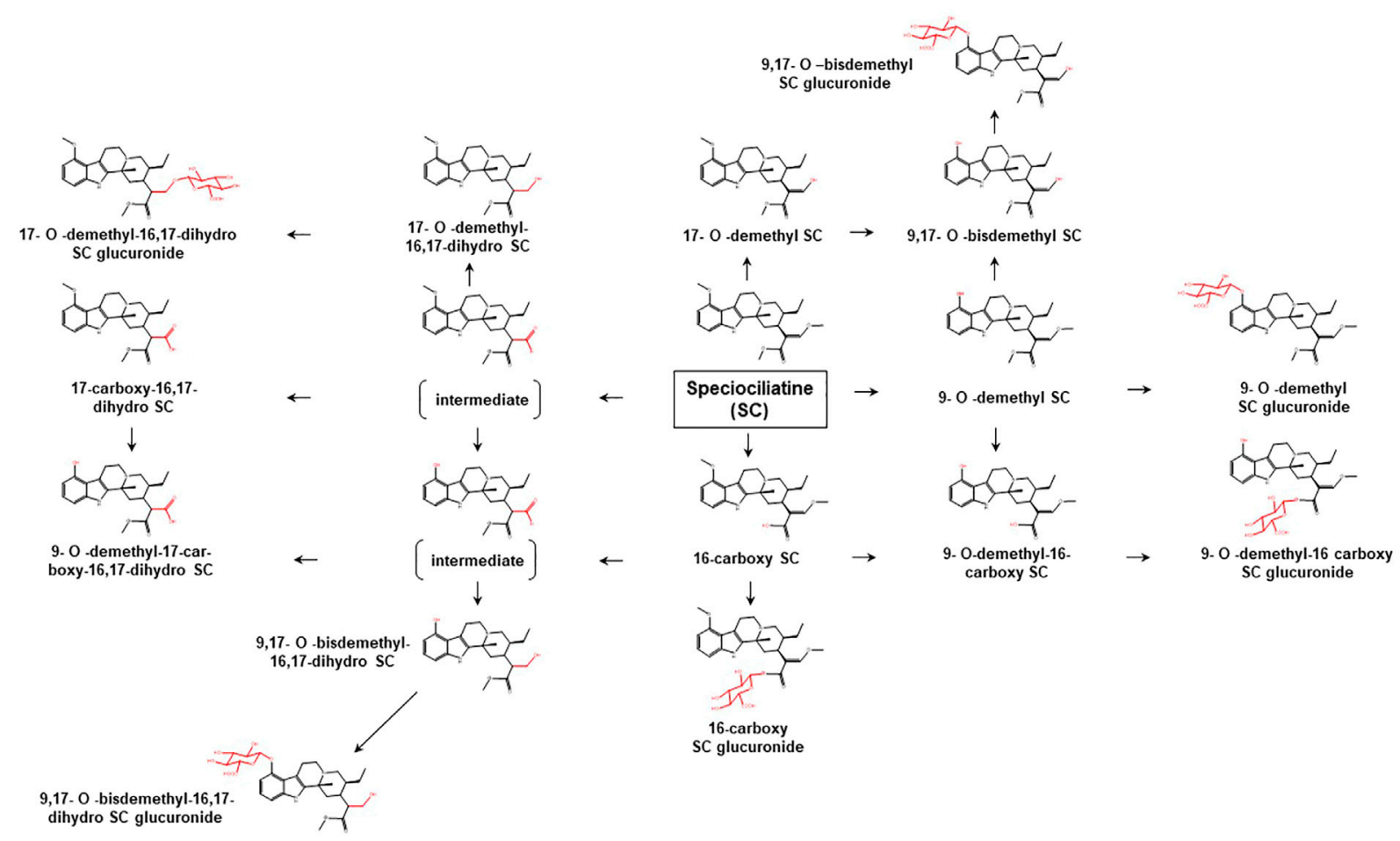

FIGURE $\mathbf{5}$ | Proposed metabolic pathways of SC based on data obtained in rodents and humans. Structures highlighted in red denote structural transformation from parent molecule SC. Figure was modified from Philipp et al. (2011a).

the alkaloids was evaluated ex vivo by measuring electricallyinduced twitch contraction in guinea pig ileum. Receptor binding affinities of the alkaloids at guinea pig $\mu, \kappa$, and $\delta$ opioid receptors were determined by radioligand displacement assay against $\left[{ }^{3} \mathrm{H}\right]$ DAMGO, $\left[{ }^{3} \mathrm{H}\right] \mathrm{DPDPE}$, and $\left[{ }^{3} \mathrm{H}\right] \mathrm{U} 69593$ respectively. In guinea pig ileum, mitragynine inhibited the electrically-induced twitch contraction with a pD2 value of 6.59, which was reversed by naloxone (300 nM). The $\mathrm{pD} 2$ or also known as $\mathrm{pEC}_{50}$ is the negative logarithm to base 10 of the $\mathrm{EC}_{50}$ of an agonist which indicates the potency but not the efficacy of the agonist. This suggests that mitragynine acted as an opioid agonist, but one that is weaker than morphine $(\mathrm{pD} 2=7.17)$. Both the oxidized mitragynine i.e., 7-hydroxymitragynine and mitragynine pseudoindoxyl showed greater opioid agonistic activity than their precursor with pD2 values of 8.20 and 8.71 respectively. The two alkaloids were also more potent than morphine with relative potencies of 1,071 and $3,467 \%$. Relative potency is defined as a percentage of the $\mathrm{pD} 2$ value of the tested compound against the reference drug, in this case, morphine. Mitragynine, 7-hydroxymitragynine, and mitragynine pseudoindoxyl showed selective binding affinities to the $\mu$-opioid receptor in the radioligand binding assay against $\left[{ }^{3} \mathrm{H}\right] \mathrm{DAMGO}$, indicating that the alkaloids were $\mu$-opioid receptor agonists. Speciociliatine on the other hand was found to weakly inhibit the twitch contraction with a relative potency of $2 \%(\mathrm{pD} 2=5.40)$. Corynantheidine (9-demethylated mitragynine) did not show opioid agonistic activity in the guinea pig ileum model. However, corynantheidine was later discovered to inhibit morphine-induced twitch contraction in guinea pig ileum with selective binding affinity to the $\mu$-opioid receptor. This finding suggests that corynantheidine is a functional and selective $\mu$-opioid receptor antagonist. Based on the above findings, it could be postulated that 1) $S$-orientation at the C3 position of mitragynine is important for opioid-agonistic activity; 2) oxidation at indole B-ring enhances the opioidagonistic activity; 3 ) the loss of $\mathrm{Nb}$ lone pair at $\mathrm{C}$-ring abolishes the opioid agonistic activity; 4) the loss of 9methoxy group abolishes the opioid-agonistic activity.

For the past 5 years, the interactions of kratom alkaloids with human opioid receptors have been extensively studied using various in vitro and in vivo assays. Kruegel et al. investigated binding affinity and functionality of mitragynine, 7hydroxymitragynine, speciociliatine, speciogynine and paynantheine at human $\mu$ (hMOR), $\delta$ (hDOR) and к (hKOR) opioid receptors using radioligand displacement and bioluminescence resonance energy transfer (BRET) functional assays (Kruegel et al., 2016). In general, the indole-based kratom alkaloids showed greater binding affinities at hMOR and hKOR with $\mathrm{K}_{\mathrm{i}}$ values in submicromolar and micromolar ranges compared to hDOR $\left(\mathrm{K}_{\mathrm{i}}>10 \mu \mathrm{M}\right)$. Among the tested alkaloids, 7-hydroxymitragynine had the highest and selective affinity for hMOR with a $K_{i}$ value of $47 \mathrm{nM}$, followed by mitragynine $\left(\mathrm{K}_{\mathrm{i}}=\right.$ $233 \mathrm{nM})$, paynantheine $\left(\mathrm{K}_{\mathrm{i}}=410 \mathrm{nM}\right)$, speciociliatine $\left(\mathrm{K}_{\mathrm{i}}=\right.$ $560 \mathrm{nM})$, and speciogynine $\left(\mathrm{K}_{\mathrm{i}}=728 \mathrm{nM}\right)$. In addition, 7- 


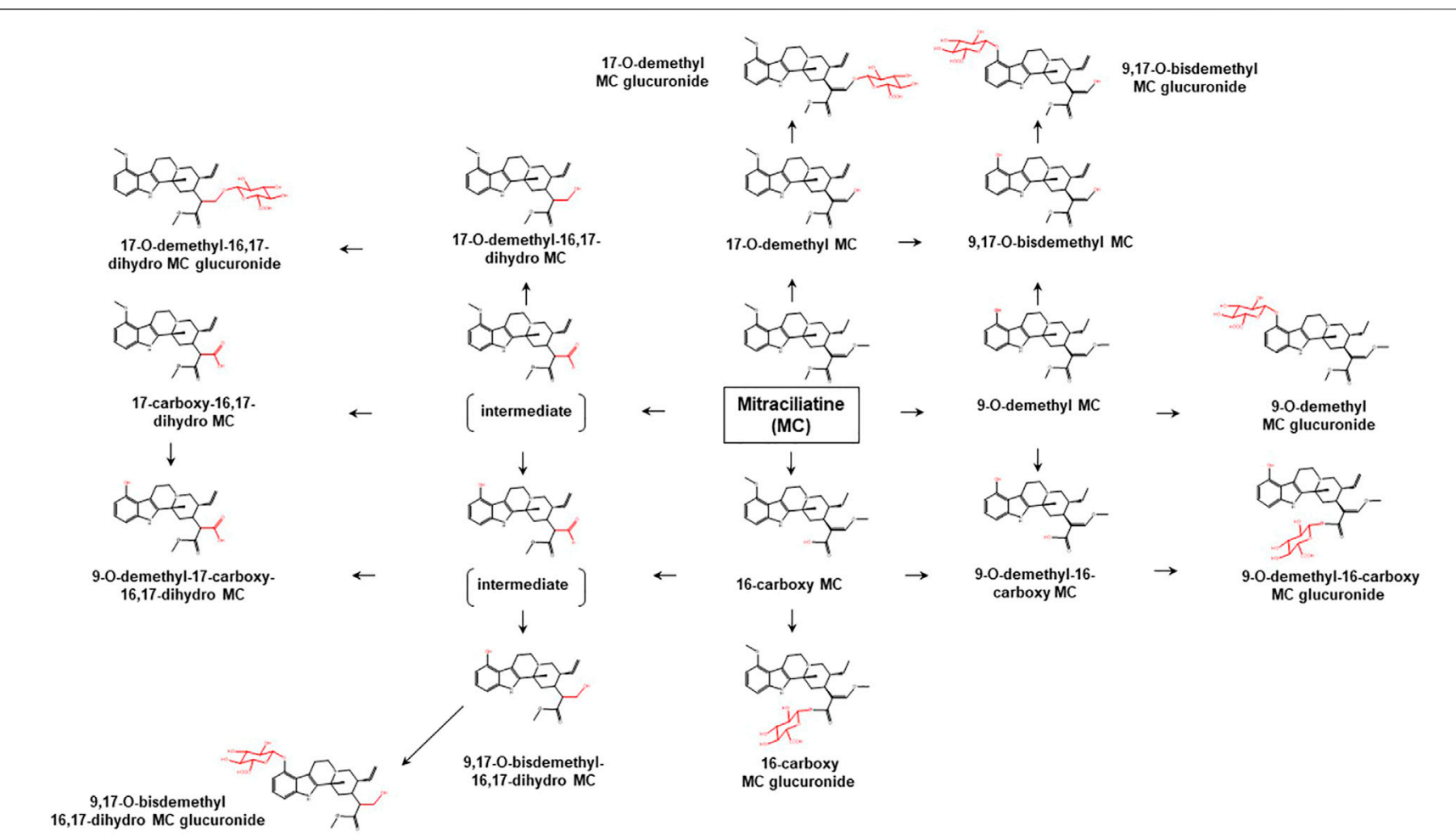

FIGURE 6 | Proposed metabolic pathways of MC based on data obtained in rodents and humans. Structures highlighted in red denote structural transformation from parent molecule MC. Figure was modified from Philipp et al. (2011b).

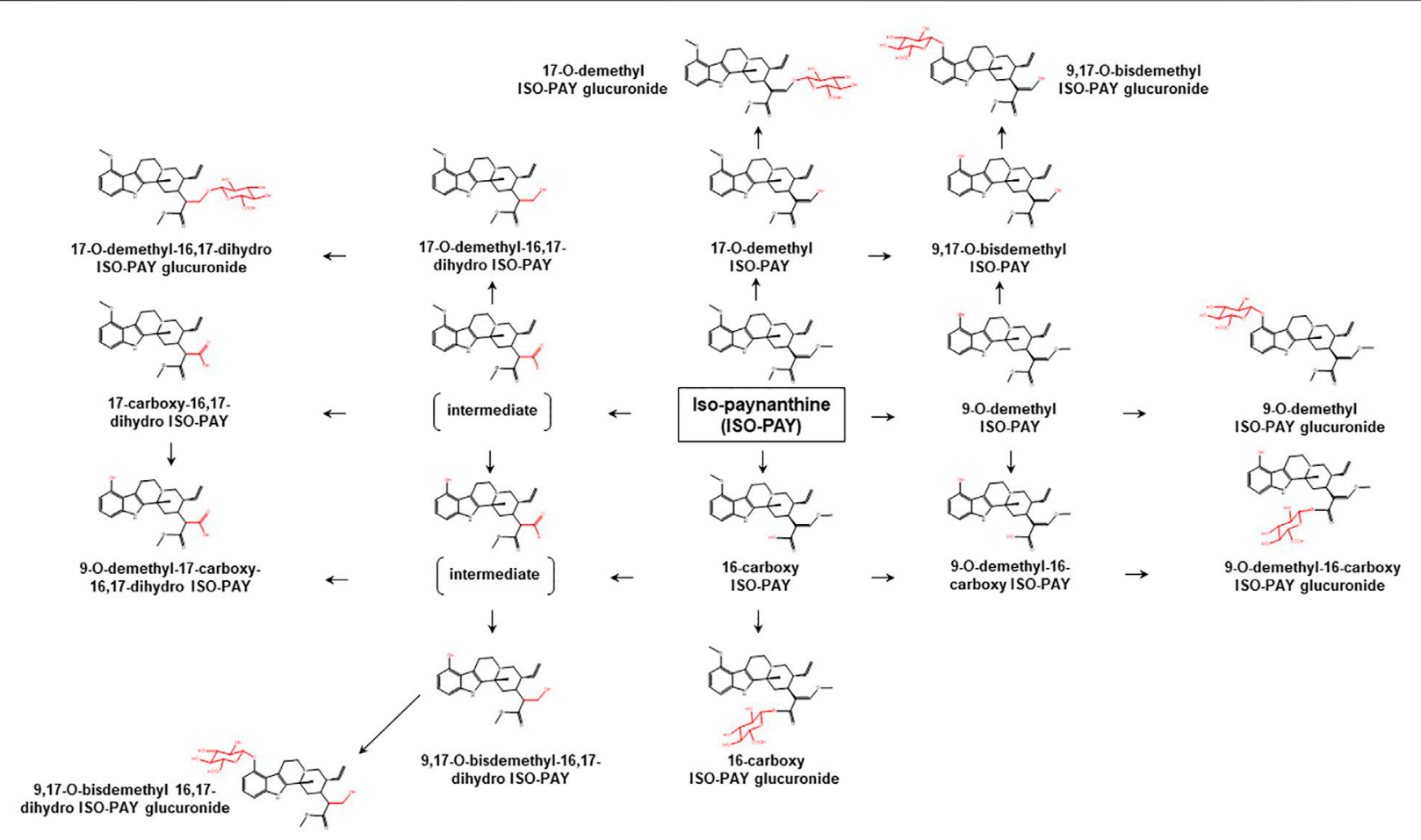

FIGURE 7 | Proposed metabolic pathways of ISO-PAY based on data obtained in rodents and humans. Structures highlighted in red denote structural transformation from parent molecule ISO-PAY. Figure was modified from Philipp et al. (2011b). 
TABLE 2 | Extent of mitragynine and related alkaloids inhibition on major human drug metabolizing enzymes (DMEs).

\begin{tabular}{|c|c|c|c|c|c|c|}
\hline References & Enzyme system & $\begin{array}{l}\text { CYPs } \\
\text { isoform }\end{array}$ & Alkaloids & Key findings & $\begin{array}{l}\text { Prediction } \\
\text { to } \\
\text { clinical DDI } \\
\text { is } \\
\text { possible? }\end{array}$ & $\begin{array}{l}\text { Following } \\
\text { FDA/EMA } \\
\text { guideline? }\end{array}$ \\
\hline $\begin{array}{l}\text { Tanna et al. } \\
(2021)\end{array}$ & $\begin{array}{l}\text { Human liver microsomes; } \\
\text { human intestinal } \\
\text { microsomes }\end{array}$ & $\begin{array}{l}\text { 2C19, } \\
2 \mathrm{D} 6,3 \mathrm{~A}\end{array}$ & Mitragynine & $\begin{array}{l}\text { Mitragynine is a competitive inhibitor for } \\
\text { CYP2D6 }\left(\mathrm{K}_{\mathrm{i}}=1.17 \mu \mathrm{M}\right) \\
\text { Mitragynine is a mechanism-based } \\
\text { inhibitor for CYP3A4 }\left(\mathrm{HLM}: \mathrm{K}_{\mathrm{I}}=4.1 \mu \mathrm{M} \text {, }\right. \\
\mathrm{K}_{\text {inact }}=0.068 \mathrm{~min}^{-1} ; \mathrm{HIM}: \mathrm{K}_{\mathrm{I}}=4.2 \mu \mathrm{M} \text {, } \\
\left.\mathrm{K}_{\text {inact }}=0.079 \mathrm{~min}^{-1}\right)\end{array}$ & Yes & Yes \\
\hline $\begin{array}{l}\text { Todd et al. } \\
\text { (2020) }\end{array}$ & Human liver microsomes & $2 \mathrm{C} 9,2 \mathrm{D} 6,3 \mathrm{~A}$ & $\begin{array}{l}\text { Mitragynine, } 7 \text { - } \\
\text { hydroxymitragynine, and } \\
\text { speciofoline }\end{array}$ & $\begin{array}{l}\text { Mitragynine at } 100 \mu \mathrm{M} \text { inhibit }>80 \% \text { for } \\
\text { CYP2C9, CYP2D6, and CYP3A } \\
\text { 7-Hydroxymitragynine at } 100 \mu \mathrm{M} \text { inhibit } \\
>80 \% \text { for CYP2D } 6 \\
\text { Speciofoline at } 100 \mu \mathrm{M} \text { inhibit }>80 \% \text { for } \\
\text { CYP2C9 and CYP3A }\end{array}$ & No & No \\
\hline $\begin{array}{l}\text { Kamble et al. } \\
\text { (2020) }\end{array}$ & Human liver microsomes & $\begin{array}{l}1 \mathrm{~A} 2,2 \mathrm{C} 8 \\
2 \mathrm{C} 9,2 \mathrm{C} 19 \\
2 \mathrm{D} 6,3 \mathrm{~A} 4 / 5\end{array}$ & $\begin{array}{l}\text { Mitragynine, speciogynine, } \\
\text { speciociliatine, } \\
\text { corynantheidine, } 7 \text { - } \\
\text { hydroxymitragynine, and } \\
\text { paynantheine }\end{array}$ & $\begin{array}{l}\text { Mitragynine and corynantheidiene is a } \\
\text { competitive inhibitor for CYP2D } 6 \text { activity } \\
\text { with } \mathrm{K}_{\mathrm{i}} \text { values of } 1.1 \text { and } 2.8 \mu \mathrm{M} \\
\text { respectively }\end{array}$ & Yes & Yes \\
\hline $\begin{array}{l}\text { Hanapi et al. } \\
\text { (2013) }\end{array}$ & $\begin{array}{l}\text { Baculovirus hCYP450 } \\
\text { Expression system } \\
\text { (baculosomes); human liver } \\
\text { cancer cell line (HepG2) }\end{array}$ & $\begin{array}{l}\text { 1A2, } \\
2 \mathrm{D} 6,3 \mathrm{~A} 4\end{array}$ & Mitragynine & $\begin{array}{l}\text { Mitragynine is a non-competitive inhibitor } \\
\text { for CYP2C9 }\left(K_{i}=61.48 \mu M\right) \text { and } \\
\text { CYP2D6 }\left(K_{i}=12.86 \mu M\right) \\
\text { Mitragynine is a competitive inhibitor for } \\
\text { CYP3A4 }\left(K_{i}=379.18 \mu M\right)\end{array}$ & Yes & No \\
\hline $\begin{array}{l}\text { Lim et al. } \\
(2013)\end{array}$ & $\begin{array}{l}\text { Baculovirus hCYP450 } \\
\text { Expression system } \\
\text { (baculosomes) }\end{array}$ & $\begin{array}{l}\text { 2C9, } \\
2 \mathrm{D} 6,3 \mathrm{~A} 4\end{array}$ & Mitragynine & $\begin{array}{l}\text { Mitragynine inhibit CYP3A4 with } \mathrm{IC}_{50} \\
\text { value } 3.98 \mu \mathrm{M} \text { (testosterone) and } \\
17.3 \mu \mathrm{M} \text { (midazolam) } \\
\text { Mitragynine induce CYP1A2 mRNA and } \\
\text { protein expression as well as enzyme } \\
\text { activity }\end{array}$ & Yes & No \\
\hline
\end{tabular}

HLM, human liver microsomes; HIM, human intestinal microsomes; $K_{i}$ reversible inhibition constant; $K_{l}$, time-dependent inhibition constant; $K_{\text {inact }}$ maximum rate of inactivation.

hydroxymitragynine was also bound to hKOR and hDOR with $\mathrm{K}_{\mathrm{i}}$ values of 188 and $219 \mathrm{nM}$ respectively. In the BRET assay, mitragynine and 7-hydroxymitragynine showed potent agonistic activity at hMOR with $\mathrm{EC}_{50}$ values of 339 and $34.5 \mathrm{nM}$ respectively. The two alkaloids acted as partial agonists at hMOR with maximal efficacy, $\mathrm{E}_{\max }$ of 34 and $47 \%$ respectively, when compared to the full agonist DAMGO in antagonist experiments. In contrast, at hKOR, mitragynine and 7-hydroxymitragynine acted as competitive antagonists with $\mathrm{IC}_{50}$ values of 8.5 and $7.9 \mu \mathrm{M}$, and $\mathrm{pA} 2$ values of 1.4 and $0.49 \mu \mathrm{M}$ respectively, when compared to the reference agonist $\mathrm{U}$ 50488. The pA2 reflects the affinity of an antagonist to a receptor. The value of $\mathrm{pA} 2$ is a negative logarithm of the molar concentration of the competitive antagonist, implying that the agonist concentration must be doubled to compensate for the antagonist's action. Paynantheine, speciogynine, and speciocilatine showed weak competitive antagonist activities at both $\mathrm{hMOR}$ and $\mathrm{hKOR}$ with $\mathrm{EC}_{50}$ or $\mathrm{IC}_{50}$ values in micromolar ranges. Interestingly, all tested kratom alkaloids were also reported as competitive antagonists at mouse MOR, indicating the possibility of intra-species variation between the in vitro functional assays. Later in 2020, Obeng et al. also reported the opioid-like activity of selected indole-based kratom alkaloids i.e., 7-hydroxymitragynine, mitragynine, speciociliatine, and corynantheidine using radioligand displacement and homogenous time-resolved fluorescence (HTRF) assays (Obeng et al., 2020). In the study, 7-hydroxymitragynine was predominantly bound to hMOR $(\mathrm{Ki}=7.16 \mathrm{nM})$, followed by $\operatorname{hKOR}\left(\mathrm{K}_{\mathrm{i}}=74.1 \mathrm{nM}\right)$ and hDOR $\left(\mathrm{K}_{\mathrm{i}}=236 \mathrm{nM}\right)$. The binding strength of kratom alkaloids at hMOR was reported as follows: 7hydroxymitragynine $\left(\mathrm{K}_{\mathrm{i}}=7.16 \mathrm{nM}\right)>$ speciociliatine $\left(\mathrm{K}_{\mathrm{i}}=\right.$ $54.5 \mathrm{nM})>$ corynantheidine $\left(\mathrm{K}_{\mathrm{i}}=118 \mathrm{nM}\right)>$ mitragynine $\left(\mathrm{K}_{\mathrm{i}}\right.$ $=161 \mathrm{nM}$ ). Similarly, 7-hydroxymitragynine also exhibited the highest binding affinity to hKOR with a $\mathrm{K}_{\mathrm{i}}$ value of $74.1 \mathrm{nM}$, followed by speciociliatine $\left(K_{i}=116 n M\right)$, mitragynine $\left(K_{i}=\right.$ $198 \mathrm{nM})$, and corynantheidine $\left(\mathrm{K}_{\mathrm{i}}=1910 \mathrm{nM}\right)$. In the HTRF assay, 7-hydroxymitragynine acted as a full agonist at hMOR $\left(\mathrm{EC}_{50}=7.6 \mathrm{nM}\right)$, and competitive antagonist at both hKOR and hDOR. Both mitragynine and speciociliatine were partial agonists at hMOR with $\mathrm{EC}_{50}$ values of 307.5 and $39.2 \mathrm{nM}$ respectively. The in vivo opioid agonistic activities of 7-hydroxymitragynine, speciociliatine, and mitragynine were then evaluated using the hot-plate test in rats. Speciociliatine produced antinociceptive response with an $\mathrm{ED}_{50}$ value of $6.25 \mathrm{mg} / \mathrm{kg}$, which was 
comparable to morphine $\left(\mathrm{ED}_{50}=5.10 \mathrm{mg} / \mathrm{kg}\right)$ but weaker than 7 hydroxymitragynine $\left(\mathrm{ED}_{50}=1.91 \mathrm{mg} / \mathrm{kg}\right)$. Similar to the in vitro hMOR binding and functional studies, mitragynine also exhibited the weakest antinociceptive effect $\left(\mathrm{E}_{\max } 17.3 \%\right)$ among the tested alkaloids at the highest dose tested $(10 \mathrm{mg} / \mathrm{kg}$, i.v.). The antinociceptive action of speciociliatine, 7-hydroxymitragynine, mitragynine, and morphine were fully antagonized by naltrexone $(0.1 \mathrm{mg} / \mathrm{kg}$, i.v.). In the study, speciociliatine demonstrated opioid agonistic activity at hMOR, which is in contrast with findings reported by Kruegel et al. (2016) where the compound showed weak antagonistic activity at hMOR in vitro. The finding also contrasted with Takayama et al. (2002), who found that speciociliatine had negligible opioid agonistic activity in the guinea pig ileum model. The discrepancies could be due to the different types of assays used to assess the functional effect of speciociliatine. Nonetheless, based on both in vitro and in vivo functional assays, it is possible to hypothesize that the $R$ orientation at the $\mathrm{C}-3$ position of speciociliatine enhances its interaction with hMOR, resulting in improved antinociceptive activity compared to mitragynine.

Although indole-based kratom alkaloids have received a lot of attention, little is known about the binding affinity and functional activity of minor oxindole alkaloids. A recent study by Chear et al. (2021) showed that the oxindole alkaloids i.e., corynoxine, corynoxine $\mathrm{B}$, mitragynine oxindole $\mathrm{B}$, and isospeciofoline were predominantly bound to hMOR $\left(\mathrm{K}_{\mathrm{i}}<2 \mu \mathrm{M}\right)$ compared to hKOR and hDOR $\left(\mathrm{K}_{\mathrm{i}}>10 \mu \mathrm{M}\right)$. At hMOR, corynoxine exhibited the highest binding affinity with a $\mathrm{K}_{\mathrm{i}}$ value of $16.4 \mathrm{nM}$, which is approximately 5 times greater than its C-7 stereoisomer, corynoxine $\mathrm{B}\left(\mathrm{K}_{\mathrm{i}}=109.8 \mathrm{nM}\right)$. On the other hand, mitragynine oxindole $\mathrm{B}$ and isospeciofoline were moderately bound to hMOR indicating the substitution at the C-9 position of corynoxine/corynoxine $\mathrm{B}$ reduces the affinity to $\operatorname{hMOR}\left(\mathrm{K}_{\mathrm{i}}>1,000 \mathrm{nM}\right)$. The in vivo functional effect of corynoxine was then evaluated using the hot-plate test in rats. The results showed that corynoxine dose-dependently increased antinociception with an $\mathrm{ED}_{50}$ value of $6.72 \mathrm{mg} / \mathrm{kg}$ which is more potent than morphine $\left(\mathrm{ED}_{50}=12.1 \mathrm{mg} / \mathrm{kg}\right)$. The antinociception of both corynoxine and morphine was also reversed by naltrexone $(0.1 \mathrm{mg} / \mathrm{kg}$, i.v.), suggesting that the compounds act as $\mu$-opioid receptor agonists. Interestingly, corynantheidine, an indole precursor of corynoxine/corynoxine $\mathrm{B}$, was discovered to be a functional $\mu$-opioid receptor antagonist (Takayama et al., 2002). The oxidative rearrangement of the indole B-ring caused the shift in $\mu$-opioid antagonistic to agonistic activity. Overall, the above findings suggest that indole and oxindole-based kratom alkaloids could be useful leads for developing new analgesics with fewer side effects that are not derived from morphinan analgesics.

\subsection{Adrenergic Receptors}

In addition to opioid receptors, the adrenergic neurotransmitter system is another major pharmacological target of kratom in treating pain and opioid withdrawal symptoms. Mitragynine was the first kratom alkaloid proven to exert antinociceptive action in rodents via activation of the central adrenergic system. In the hotplate test, pretreatment with idazoxan $(10 \mu \mathrm{g})$ was able to reverse the antinociceptive action of mitragynine $(10 \mu$ g, i.c.v. $)$ in mice
(Matsumoto et al., 1996b). Yohimbine (alpha-2 adrenoreceptor antagonist) and prazosin (alpha-1 adrenoreceptor antagonist) also totally and partially suppressed mitragynine antinociceptive activity in a chemotherapy-induced neuropathic pain rat model respectively (Foss et al., 2020). However, information on the specific binding of mitragynine or other kratom alkaloids to various subtypes of alpha-1 and alpha-2 adrenergic receptors is still lacking. As a result, the potential radioligand binding affinities of mitragynine and other indole-based kratom alkaloids i.e. speciogynine, 7hydroxymitragynine, speciociliatine, corynantheidine, ajmalicine, and tetrahydroalstonine at alpha-1A, 1B, and 1D, and alpha-2A, $2 \mathrm{~B}$, and $2 \mathrm{C}$ adrenergic receptors were investigated using a high throughput screening approach (Ellis et al., 2020; Obeng et al., 2020). Mitragynine was found to have moderate and non-selective binding affinities at alpha-1A, 1B, and $1 \mathrm{D}$, and alpha- $2 \mathrm{~A}, 2 \mathrm{~B}$, and $2 \mathrm{C}$, with $\mathrm{K}_{\mathrm{i}}$ values in the low micromolar range $(1.3-9.29 \mu \mathrm{M})$. Corynantheidine exhibited high and selective binding affinity at alpha-1D but not alpha-2 adrenergic receptors, with a $\mathrm{K}_{\mathrm{i}}$ value of $41.7 \mathrm{nM}$, which is comparable to prazosin, a selective alpha-1D blocker $\left(\mathrm{K}_{\mathrm{i}}=0.17 \mathrm{nM}\right)$ (Obeng et al., 2020). Interestingly, the binding affinity of both mitragynine diastereoisomers i.e. speciociliatine and speciogynine varied at the alpha- 2 subtypes. Speciogynine displayed non-selective binding affinities for alpha-2A, 2B, and $2 \mathrm{C}$ adrenergic receptors, with $\mathrm{K}_{\mathrm{i}}$ values ranging from 0.36 to $2.6 \mu \mathrm{M}$, similar to its diastereoisomer at the C-20 (mitragynine). Speciociliatine on the other hand was discovered to be less active $\left(\mathrm{K}_{\mathrm{i}}>10 \mu \mathrm{M}\right)$, implying that the $S$-orientation at the C-3 of mitragynine (speciogynine) is required for binding to alpha$2 \mathrm{~A}, 2 \mathrm{~B}$, and $2 \mathrm{C}$ adrenergic receptors.

Unlike mitragynine, 7-hydroxymitragynine had little to no binding affinity to both alpha-1 and alpha-2 adrenoreceptors indicating that oxidation at the $\mathrm{C}-7$ abolishes the interaction with these receptors. Both pentacyclic kratom alkaloids i.e. ajmalicine and tetrahydroalstonine showed higher binding affinities on alpha-2A, 2B, and $2 \mathrm{C}$ receptors, with $\mathrm{K}_{\mathrm{i}}$ values in the submicromolar range $\left(\mathrm{K}_{\mathrm{i}}=18-65 \mathrm{nM}\right)$ than tetracyclic kratom alkaloids $\left(\mathrm{K}_{\mathrm{i}}\right.$ values in the micromolar range). This shows that, like yohimbine (a potent but non-selective alpha-2 adrenergic antagonist with $\mathrm{K}_{\mathrm{i}}$ values $<5 \mathrm{nM}$ ), the ring-D of ajmalicine and tetrahydroalstonine is a critical characteristic for displaying binding to alpha-2A, $2 \mathrm{~B}$, and $2 \mathrm{C}$ adrenergic receptors (Obeng et al., 2020). The major kratom alkaloids such as mitragynine and speciogynine showed significant binding affinities at alpha-2A, $2 \mathrm{~B}$, and $2 \mathrm{C}$ adrenergic receptors, which could contribute to kratom overall antinociceptive effect. However, additional research is needed to determine whether the alkaloids work as agonists or antagonists on human adrenergic receptors.

\subsection{Serotonin Receptors}

Serotonin (5-HT) receptors are a class of G-protein-coupled receptors (GPCRs) and ligand-gated ion channels that regulate physiological functions including mood, cognition, sleep, sociability, blood pressure, body temperature, and sexual behavior, through their natural ligand serotonin (Hoyer et al., 1994; Beliveau et al., 2017). 5-HT receptors are known to have at 
least 14 subtypes from seven distinct families, 5-HT1-5-HT7 (Nichols and Nichols, 2008). Kratom has long been used as a mood enhancer, mild stimulant, or aphrodisiac in traditional settings in Malaysia and Thailand (Singh et al., 2019; Singh et al., 2020b). However, research into its potential interaction with the human serotonin neurotransmission system is still in its early stages.

Matsumoto et al. (1997) reported that mitragynine has a suppressive effect on the central serotonin neurotransmission system. In rodents, pretreatment with mitragynine (i.p.) or ritaserin (i.p.) significantly suppressed the 5-HT2A agonist (5methoxy-N,N-dimethyltryptamine)-induced head twitch response. The results showed that mitragynine, like ritaserin, acts as a competitive antagonist, blocking the stimulation of the 5HT2A receptor. Further, mitragynine and its diastereoisomer speciogynine measured $\mathrm{K}_{\mathrm{i}}$ at $5-\mathrm{HT} 2 \mathrm{~A}$ receptor were 7.3 and $2.9 \mu \mathrm{M}$ respectively in a radioligand binding assay against $\left[{ }^{3} \mathrm{H}\right]$ clozapine (Ellis et al., 2020). In the same study, Ellis et al. also evaluated the 5-HT2A binding affinity of other kratom alkaloids including 7-hydroxymitragynine, corynoxine B, isorhynchophylline, tetrahydroalstonine, and ajmalicine. However, the alkaloids were found to weakly inhibit binding of the radioligand $\left[{ }^{3} \mathrm{H}\right]$ clozapine with $\mathrm{K}_{\mathrm{i}}$ values $>10 \mu \mathrm{M}$ except for tetrahydroalstonine $\left(\mathrm{K}_{\mathrm{i}}=2.6 \mu \mathrm{M}\right)$.

Along with the 5-HT2A receptor, indole-based kratom alkaloids such as mitragynine, speciogynine, speciociliatine, and paynantheine have been shown to interact with the 5HT1A receptor (Obeng et al., 2021). Using in vitro displacement of $\left[{ }^{3} \mathrm{H}\right] 8-\mathrm{OH}-\mathrm{DPAT}$, paynantheine was found to have the highest binding affinity at the human 5-HT1A receptor, with a $K_{i}$ value of $32 \mathrm{nM}$, followed by speciogynine $(39 \mathrm{nM})$, mitragynine $(>1,000 \mathrm{nM})$, and speciociliatine $(>1,000 \mathrm{nM})$. The in vivo binding functionality of the alkaloids at the 5-HT1A receptor was further evaluated by induction of lower lip retraction (LLR) in rats (i.p.) in reference to ipsapirone, a selective 5-HT1A partial agonist. Among the tested alkaloids, speciogynine induced the strongest LLR effect with an $\mathrm{ED}_{50}$ value of $23 \mathrm{~mol} / \mathrm{kg}$, followed by paynantheine $(26 \mathrm{~mol} / \mathrm{kg})$ and mitragynine $(62 \mathrm{~mol} / \mathrm{kg})$. However, the effects were weaker than ipsapirone $\left(\mathrm{ED}_{50}=1.1 \mathrm{~mol} / \mathrm{kg}\right)$. The LLR effects of the alkaloids and ipsapirone were reversed by the 5-HT1A receptor antagonist WAY100635 (0.019 $\mu \mathrm{mol} / \mathrm{kg}$, i.p.), suggesting that the alkaloids potentially act as 5-HT1A agonists or partial agonists, in a similar way to ipsapirone. Based on the in vitro and in vivo findings, it can be assumed that the $R$ orientation at C-20 of speciogynine and paynantheine is critical for 5-HT1A agonistic activity. The binding affinity of the alkaloids for the 5-HT1A receptor is dramatically reduced when their orientation is switched from $R$ to $S$ (mitragynine/speciociliatine). Taking all of this into account, it is hypothesized that the traditional use of kratom as a mood enhancer is due in part to the interaction of its indole-based alkaloids with the 5-HT1A and 5 -HT2A receptors.

\subsection{Dopamine Receptors}

The level of dopamine neurotransmitter in the brain is primarily regulated by a group of GPCRs known as dopamine receptors
(Beaulieu and Gainetdinov, 2011). There are a total of 5 dopamine receptor subtypes i.e., D1, D2, D3, D4, and D5 regulating emotion, locomotion, memory and learning, sleep, decision making, and the reward system in the human brain (Mishra et al., 2018). Several studies have suggested that dopaminergic receptors are involved in the antipsychotic, antidepressant, anxiolytic, and anti-addiction activities of kratom or its main alkaloid, mitragynine.

Boyer et al. (2008) were the first to report the binding potential of mitragynine to dopamine receptors, specifically the D2 subtype. In the study, mitragynine was found to moderately inhibit the radioligand binding to the D2 receptor, with a percentage inhibition of $54.22 \%$. The in vitro finding was supported by several in vivo studies utilizing approaches such as elevated plus-maze, apomorphine-induced climbing behavior, haloperidol-induced catalepsy, and ketamine-induced social withdrawal in rodents. Hazim et al. (2014) investigated the potential role of the dopaminergic system in the anxiolytic-like activity of mitragynine in the elevated plus-maze test. The findings showed that a single oral administration of mitragynine $(40 \mathrm{mg} / \mathrm{kg})$ increased the percentage of open arm entries and the time spent on open arms, in a similar way to apomorphine, a non-selective dopamine agonist. The effects were significant but not fully antagonized by sulpiride and SCH 23390 . Sulpiride is a non-selective D2-like antagonist while SCH 23390 is a selective D1 antagonist (Holanda et al., 2019). These observations suggest that mitragynine is a moderate dopamine agonist, and its anxiolytic-like activity was partly mediated by D1 and D2-like receptors. However, the findings are in contradiction to the findings reported by Vijeepallam et al. (2016) where they discovered that kratom leaf extract exhibited an antipsychoticlike effect in mice through the blockage of the central D2 receptor. Vijeepallam et al. (2016) found that pretreatment with kratom leaf extract (75 and $100 \mathrm{mg} / \mathrm{kg}$, p.o.) significantly reversed apomorphine-induced cage climbing behavior, ketamineinduced hyperactivity, and social withdrawal deficit in mice. Moreover, co-treatment with the leaf extract significantly enhanced the haloperidol-induced catalepsy in mice. Haloperidol is an antipsychotic that acts as a dopamine D2 receptor antagonist. The antidopaminergic action of the leaf extract $(1-100 \mu \mathrm{g} / \mathrm{ml})$ was further assessed in an ex-vivo study using isolated rat vas deferens preparation, and the results showed that the extract inhibited the contractility evoked by dopamine in a dose-dependent manner. However, their $\mathrm{pEC}_{50}$ values $\left(\mathrm{pEC}_{50} 1.01-1.40 \mu \mathrm{g} / \mathrm{ml}\right.$ ) were not significantly altered at different treatment doses $(1-20 \mu \mathrm{g} / \mathrm{ml})$ similar to what observed in the treatment with haloperidol $(1.6-12.8 \mu \mathrm{g} / \mathrm{ml})$ (pEC50 1.31-1.53 $\mu \mathrm{g} / \mathrm{ml}$ ). These results affirm kratom leaf extract acts as a dopamine D2 blocker/antagonist, similar to haloperidol. However, Vijeepallam's findings are in contradiction with what was reported by Hazim et al. (2014) of which mitragynine acts as a dopamine D1 or D2 agonist, and this could be caused by several factors: 1) mitragynine as a pure compound has a narrow receptor binding profile compared to kratom extract; 2) kratom leaf extract contains multicomponent which might interact with a broad range of CNS receptors leading to the differences in the observed effect; 
TABLE 3 | Radioligand binding and functional profiles of selected kratom alkaloids.

\begin{tabular}{|c|c|c|c|c|c|c|c|}
\hline References & $\begin{array}{c}\text { Membrane } \\
\text { source }\end{array}$ & Receptor & Radioligand & Alkaloids & Key findings & Binding affinity & Functional \\
\hline $\begin{array}{l}\text { Takayama } \\
\text { et al. (2002) }\end{array}$ & $\begin{array}{l}\text { Guinea pig } \\
\text { (rodent) }\end{array}$ & $\mu$-opioid & {$\left[{ }^{3} \mathrm{H}\right] \mathrm{DAMGO}$} & $\begin{array}{l}\text { Mitragynine, speciociliatine, } 7 \text { - } \\
\text { hydroxymitragynine, } \\
\text { mitragynine pseudoindoxyl, } \\
\text { corynantheidine, mitragynine } \\
\text { n-oxide }\end{array}$ & $\begin{array}{l}\text { Mitragynine, } 7 \text { - } \\
\text { hydroxymitragynine, and } \\
\text { mitragynine pseudoindoxyl act } \\
\text { as agonists at } \mu \text {-opioid } \\
\text { receptor } \\
7 \text {-hydroxymitragynine and } \\
\text { mitragynine pseudoindoxyl are } \\
\text { more potent than morphine } \\
\text { Corynantheidine is a selective } \\
\text { and functional } \mu \text {-opioid } \\
\text { antagonist }\end{array}$ & Yes & Yes (In vivo) \\
\hline
\end{tabular}

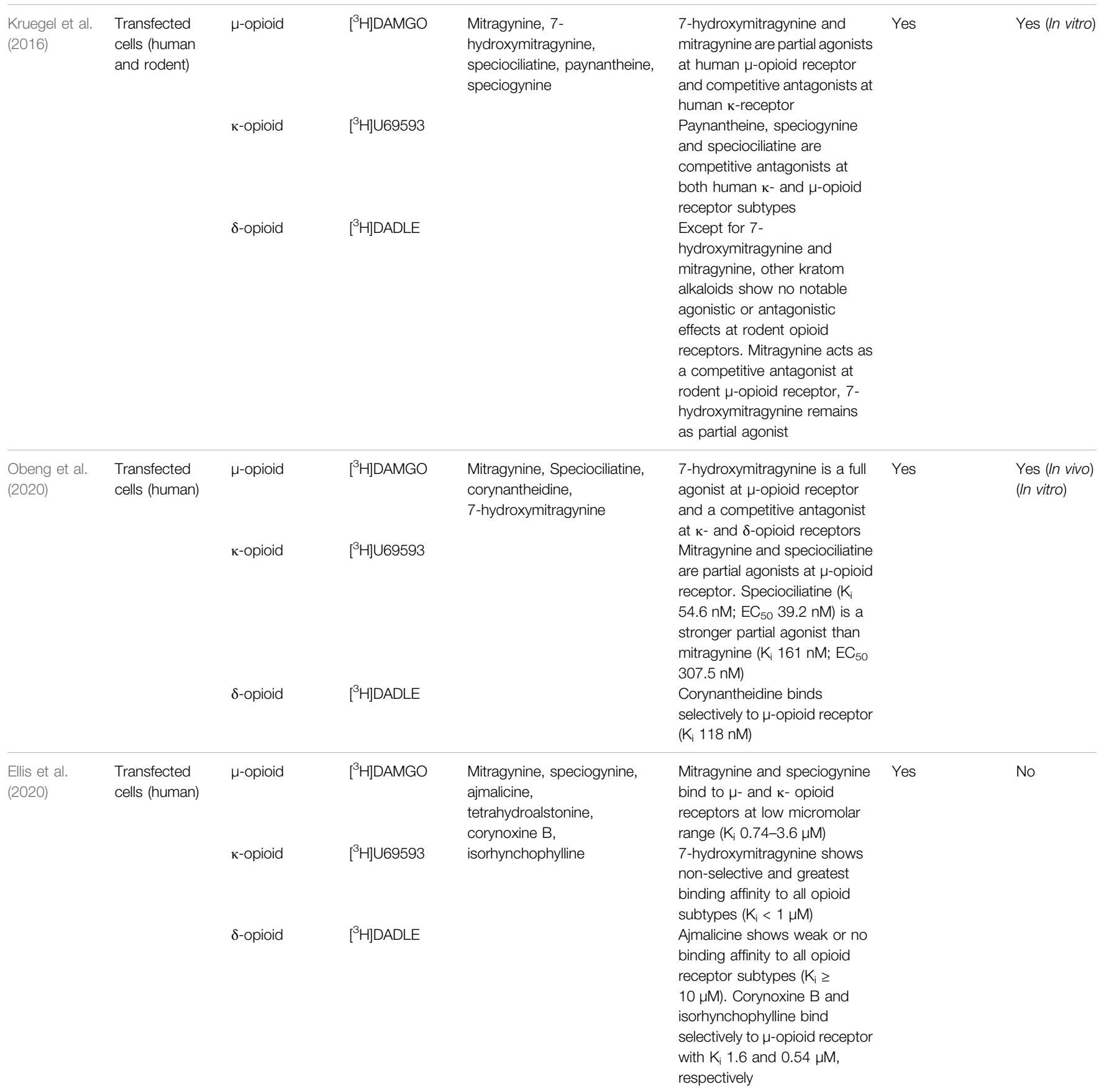


TABLE 3 | (Continued) Radioligand binding and functional profiles of selected kratom alkaloids.

\begin{tabular}{|c|c|c|c|c|c|c|c|}
\hline References & $\begin{array}{c}\text { Membrane } \\
\text { source }\end{array}$ & Receptor & Radioligand & Alkaloids & Key findings & Binding affinity & Functional \\
\hline $\begin{array}{l}\text { Chear et al. } \\
(2021)\end{array}$ & $\begin{array}{l}\text { Transfected } \\
\text { cells (human) }\end{array}$ & $\begin{array}{l}\mu \text {-opioid } \\
\kappa \text {-opioid } \\
\delta \text {-opioid }\end{array}$ & $\begin{array}{l}{\left[{ }^{3} \mathrm{H}\right] \mathrm{DAMGO}} \\
{\left[{ }^{3} \mathrm{H}\right] \mathrm{U} 69593} \\
{\left[{ }^{3} \mathrm{H}\right] \mathrm{DADLE}}\end{array}$ & $\begin{array}{l}\text { Corynoxine, corynoxine B, } \\
\text { isospeciofoline, mitragynine } \\
\text { oxindole B, Speciociliatine } \\
\text { n-oxide }\end{array}$ & $\begin{array}{l}\text { Corynoxine and corynoxine } \mathrm{B} \\
\text { exhibit strong and selective } \\
\text { binding affinity to } \mu \text {-opioid } \\
\text { receptor with } \mathrm{K}_{\mathrm{i}} 16.4 \text { and } \\
109.8 \mathrm{nM} \text {, respectively } \\
\text { Corynoxine acts as a } \mu \text {-opioid } \\
\text { receptor agonist in hot-plate } \\
\text { test ( } 10 \mathrm{mg} / \mathrm{kg} \text { ) and the effect } \\
\text { is reversed by naltrexone }\end{array}$ & Yes & Yes (In vivo) \\
\hline
\end{tabular}

\begin{tabular}{lllll}
\hline Obeng et al. & Transfected & Alpha-1A & {$\left[{ }^{3} \mathrm{H}\right]$ prazosin } & Mitragynine, speciociliatine, \\
$(2020)$ & cells (human) & Alpha-1B & {$\left[{ }^{3} \mathrm{H}\right]$ prazosin } & corynantheidine, 7- \\
& & Alpha-1D & {$\left[{ }^{3} \mathrm{H}\right]$ prazosin } & hydroxymitragynine
\end{tabular}

Mitragynine binds to alpha-1

Yes

Yes (In vitro) alpha-2 subtypes ( $\mathrm{K}$

low micromolar range). Mitragynine is a partial agonist at alpha-1A,D, but acts as a competitive antagonist at alpha-1B,2C

Alpha-2A $\quad\left[{ }^{3} \mathrm{H}\right] \mathrm{R} \times 821002 \quad$ Corynantheidine binds to Alpha-2B $\quad\left[{ }^{3} \mathrm{H}\right] \mathrm{RX} 821002$ alpha-1D receptor $\left(\mathrm{K}_{\mathrm{i}} 41.7 \mathrm{nM}\right)$

$\begin{array}{ll}\text { Alpha-2A } & {\left[{ }^{3} \mathrm{H}\right] \mathrm{RX} 821002} \\ \text { Alpha-2B } & {\left[{ }^{3} \mathrm{H}\right] \mathrm{RX821002}} \\ \text { Alpha-2C } & {\left[{ }^{3} \mathrm{H}\right] \mathrm{RX} 821002}\end{array}$

\begin{tabular}{|c|c|c|c|}
\hline $\begin{array}{l}\text { Ellis et al. } \\
(2020)\end{array}$ & $\begin{array}{l}\text { Transfected } \\
\text { cells (human) }\end{array}$ & Alpha-2A & $\begin{array}{l}{\left[{ }^{3} \mathrm{H}\right]} \\
\text { rauwolscine }\end{array}$ \\
\hline
\end{tabular}

Mitragynine, speciogynine, 7hydroxymitragynine, ajmalicine, corynoxine B, isorhynchophylline

Mitragynine and speciogynine Yes

show non-selective binding

affinity to all subtypes at low

micromolar range $\left(\mathrm{K}_{\mathrm{i}}\right.$

$0.36-4.9 \mu \mathrm{M})$

Alpha-2B

Oxygenated or oxindole alkaloids $\mathrm{K}_{\mathrm{i}}>10 \mu \mathrm{M}$ for adrenergic receptors (not active)

Alpha-2C

Ajmalicine exhibits nonselective binding affinity to all alpha-2 subtypes $\left(\mathrm{K}_{\mathrm{i}}\right.$ 18-65 nM)

\begin{tabular}{|c|c|c|c|c|}
\hline $\begin{array}{l}\text { Ellis et al. } \\
(2020)\end{array}$ & $\begin{array}{l}\text { Transfected } \\
\text { cells (human) }\end{array}$ & $\begin{array}{l}\text { 5-HT1A } \\
5-\mathrm{HT} 2 \mathrm{~A}\end{array}$ & $\begin{array}{l}{\left[{ }^{3} \mathrm{H}\right] 8-\mathrm{OH}-} \\
\text { DPAT } \\
{\left[{ }^{3} \mathrm{H}\right] \text { clozapine }}\end{array}$ & $\begin{array}{l}\text { Mitragynine, speciogynine, } \\
\text { ajmalicine, } \\
\text { tetrahydroalstonine, } \\
\text { corynoxine B, } \\
\text { isorhynchophylline }\end{array}$ \\
\hline
\end{tabular}

Mitragynine and speciogynine

$\mathrm{K}_{\mathrm{i}}$ 0.54-7.3 $\mu \mathrm{M}$

Ajmalicine and tetrahydroalstonine $5-\mathrm{HT} 1 \mathrm{~A} \mathrm{~K}$ $<0.5 \mu \mathrm{M}$. Oxygenated indole and oxindole alkaloids

\begin{tabular}{|c|c|c|c|c|}
\hline $\begin{array}{l}\text { Obeng et al. } \\
(2021)\end{array}$ & $\begin{array}{l}\text { Transfected } \\
\text { cells (human) }\end{array}$ & $5-\mathrm{HT} 1 \mathrm{~A}$ & $\begin{array}{l}{\left[{ }^{3} \mathrm{H}\right] 8-\mathrm{OH}-} \\
\text { DPAT }\end{array}$ & $\begin{array}{l}\text { Mitragynine, paynantheine, } \\
\text { speciogynine, speciociliatine }\end{array}$ \\
\hline
\end{tabular}

Binding affinity: paynantheine
$(32 \mathrm{nM})>$ speciogynine
$(39 \mathrm{nM})>$ mitragynine
$(>1,000 \mathrm{nM})$ and
speciociliatine (>1,000 nM)
Speciogynine, paynantheine
and mitragynine are 5-HT1A
agonists

\begin{tabular}{|c|c|c|c|c|c|c|c|}
\hline $\begin{array}{l}\text { Boyer et al. } \\
\text { (2008) }\end{array}$ & Not specified & $\begin{array}{l}\mu \text {-opioid; } \\
\text { к-opioid; } \\
\text { §-opioid; } \\
\text { Alpha-2; D2; 5- } \\
\text { HT2C; 5- } \\
\text { HT7; A2A }\end{array}$ & Not specified & Mitragynine & $\begin{array}{l}\text { Mitragynine binds to } \mu \text { and } \\
\kappa \text {-opioid receptors ( } 90 \% \\
\text { inhibition) but not } \delta \text {-opioid } \\
\text { receptor }\end{array}$ & $\begin{array}{l}\text { No } \\
\text { (\% inhibition of } \\
\text { radioligand } \\
\text { binding at single } \\
\text { dose screening) }\end{array}$ & No \\
\hline
\end{tabular}


3) dose-dependent presynaptic (functional antagonistic) and postsynaptic (agonistic) action of kratom and mitragynine at dopamine receptors. Therefore, more research is needed to determine the specific binding profile of mitragynine and other kratom alkaloids at dopamine receptors using in vitro radioligand binding assays.

Summary of interactions of kratom alkaloids with CNS receptors is tabulated in Table 3 .

\section{INTERACTIONS OF KRATOM ALKALOIDS WITH CELLULAR BARRIERS}

Cellular barriers formed by epithelium that lined tissue cavities and endothelium that lined blood vessels delineate tissue compartments and play a pivotal role in maintaining homeostasis, and protecting the tissue microenvironment. The barriers function as a gatekeeper, regulating the passage of substances across the tissue compartments through restrictive tight junctions between adjacent cells; and concerted action of transporters that transport essential nutrients required by the tissues, and keeping out xenobiotics and other harmful substances (Abbott et al., 2010; Vancamelbeke and Vermeire, 2018). In drug discovery and development, it is acknowledged that the barriers imposed a significant hurdle due to the restrictive nature of the barriers which would limit successful delivery of therapeutic molecules to the site of action. It is also known that the functions of the barriers are altered in pathophysiology (Chelakkot et al., 2018; Sweeney et al., 2019). Here, interactions of kratom alkaloids with cellular barriers are discussed within the scope of barrier permeability of the alkaloids, involvement with transporters expressed at the barriers, and effects of the alkaloids on the barrier function.

\subsection{Barrier Permeability}

The most widely used method to measure barrier permeability is by utilizing two-dimensional in vitro cell-based models. The models are established by culturing epithelial or endothelial cells on semi-permeable membrane of well-plate inserts to yield confluent cell monolayers. Determination of barrier properties of the cells particularly tight junction tightness and functional expression of polarized membrane transporters are carried out to evaluate the goodness of purpose of the models. Following the model validation, in vitro permeability assay of a compound of interest is conducted. Quantitative analysis of the compound present in assay buffer sampled from the apical and the basolateral compartments which are separated by the cell monolayer enables determination of apparent permeability coefficient, $P_{\text {app }}$ of the compound. Comparison of the $P_{\text {app }}$ with $P_{\text {app }}$ of reference drug would give insights to the potential of barrier permeation of the compound.

For the intestinal barrier, the Caco- 2 cell line developed from human colorectal adenocarcinoma epithelium is commonly used to establish a model for the barrier, to determine intestinal absorption (Volpe, 2020). The model was used to investigate intestinal permeability of kratom alkaloids mitragynine (Manda et al., 2014; Rusli et al., 2019), 7-hydroxymitragynine, and mitraphylline (Manda et al., 2014). Mitragynine was found to be the most permeable across the Caco- 2 cells, followed by 7 hydroxymitragynine and mitraphylline with $P_{\text {app }}$ of $24.2 \times$ $10^{-6} \mathrm{~cm} / \mathrm{s}, 16.1 \times 10^{-6} \mathrm{~cm} / \mathrm{s}$ and $6.3 \times 10^{-6} \mathrm{~cm} / \mathrm{s}$ respectively, when tested at $5 \mu \mathrm{M}$ in the absorptive direction (apical to basolateral). $P_{\text {app }}$ values in the absorptive direction for the three compounds were similar when tested at $10 \mu \mathrm{M}$ (Manda et al., 2014). Rusli et al. (2019) reported comparable mitragynine $P_{\text {app }}$ of $18.8 \times 10^{-6} \mathrm{~cm} / \mathrm{s}$. The permeability of mitragynine across the intestinal barrier was also measured using in situ single-pass perfusion technique in rats (Jagabalan et al., 2019). In situ perfusion technique enables measurement of barrier permeability in an intact functional barrier with membrane transporter machinery in place (Jeong et al., 2004). The findings showed that mitragynine $P_{\text {eff }}$ was $111 \times 10^{-6} \mathrm{~cm} / \mathrm{s}$. Manda et al. (2014) and Jagabalan et al. (2019) both included high permeability reference drug i.e. propranolol in their studies. Mitragynine showed comparable permeability coefficients to the drug where $P_{\text {app }}$ of $24.2 \times 10^{-6} \mathrm{~cm} / \mathrm{s}(5 \mu \mathrm{M})$ and $25.3 \times 10^{-6} \mathrm{~cm} / \mathrm{s}$ $(10 \mu \mathrm{M})$ were measured using the in vitro Caco- 2 model while propranolol showed $P_{\text {app }}$ of $34.2 \times 10^{-6} \mathrm{~cm} / \mathrm{s}$ (Manda et al., 2014); $P_{\text {eff }}$ of $111 \times 10^{-6} \mathrm{~cm} / \mathrm{s}$ was measured using the in situ technique while propranolol showed $P_{\text {eff }}$ of $127 \times 10^{-6} \mathrm{~cm} / \mathrm{s}$ (Jagabalan et al. 2019).

Previous studies on the BBB permeability of kratom alkaloids utilized in vitro models from epithelial and endothelial cells (Manda et al., 2014; Yusof et al., 2019). Compared to endothelial cells, epithelial cell monolayer more readily shows restrictive tight junctions which is the hallmark of the BBB. However, use of primary brain endothelial cells or differentiated stem cells, and co-culture of endothelial cells with other cells of the neurovascular unit for example astrocytes could contribute to having endothelial cell monolayer with restrictive tight junctions and close phenotypic resemblance to the $\mathrm{BBB}$ in vivo (see Helms et al., 2016 for the different in vitro BBB models available). In the MDR-MDCK epithelial cell model, mitragynine and 7hydroxymitragynine showed apical to basolateral, or blood to brain side $P_{\text {app }}$ of $15.3 \times 10^{-6} \mathrm{~cm} / \mathrm{s}$ and $12.4 \times 10^{-6} \mathrm{~cm} / \mathrm{s}$ when tested at $5 \mu \mathrm{M} ; 16.2 \times 10^{-6} \mathrm{~cm} / \mathrm{s}$ and $13.2 \times 10^{-6} \mathrm{~cm} / \mathrm{s}$ when tested at $10 \mu \mathrm{M}$ respectively (Manda et al., 2014). When the two alkaloids were assayed using primary porcine brain endothelial cells, mitragynine showed apical to basolateral $P_{\text {app }}$ of $31.8 \times$ $10^{-6} \mathrm{~cm} / \mathrm{s}$, while 7-hydroxymitragynine $P_{\text {app }}$ was $15.3 \times$ $10^{-6} \mathrm{~cm} / \mathrm{s}$ (Yusof et al., 2019). Based on the two studies, mitragynine showed approximately 1.2-2.1 times higher BBB permeability than 7-hydroxymitragynine. This could potentially be contributed by differences in physicochemical properties of the alkaloids. Mitragynine being more lipophilic and 7-hydroxymitragynine being more polar might eased and hampered passive transcellular permeation respectively. Another possibility is the involvement of membrane transporters to transport the alkaloids. Meanwhile, mitraphylline apical to basolateral permeability was more restricted with $P_{\text {app }}$ of $3.3 \times$ 
TABLE 4 | Functional interactions of kratom alkaloids with efflux transporters.

\begin{tabular}{|c|c|c|c|c|c|c|}
\hline Alkaloid & $\begin{array}{c}\text { Concentration } \\
\text { tested }\end{array}$ & Methods & Findings & $\begin{array}{l}\text { Subjected } \\
\text { to } \\
\text { efflux }\end{array}$ & $\begin{array}{l}\text { Efflux } \\
\text { transporter } \\
\text { inhibition }\end{array}$ & References \\
\hline \multirow[t]{12}{*}{ Mitragynine } & $5,10 \mu \mathrm{M}$ & $\begin{array}{l}\text { In vitro bidirectional permeability assay } \\
\text { using Caco- } 2 \text { and MDR-MDCKII cells }\end{array}$ & $\begin{array}{l}\text { No polarization of transport. Efflux } \\
\text { ratio }=1.0 \text { and } 1.1\end{array}$ & No & - & $\begin{array}{l}\text { Manda et al. } \\
(2014)\end{array}$ \\
\hline & $5 \mu \mathrm{M}$ & $\begin{array}{l}\text { In vitro permeability assay using Caco- } 2 \\
\text { cells with or without P-gp inhibitor } \\
\text { verapamil }(5 \mu \mathrm{M})\end{array}$ & $\begin{array}{l}\text { Permeability was unaltered in } \\
\text { presence of verapamil }\end{array}$ & No & - & $\begin{array}{l}\text { Meyer et al. } \\
(2015)\end{array}$ \\
\hline & $10 \mu \mathrm{M}$ & $\begin{array}{l}\text { In vitro bidirectional permeability assay } \\
\text { using Caco- } 2 \text { cells }\end{array}$ & $\begin{array}{l}\text { No polarization of transport. Efflux } \\
\text { ratio }=0.9\end{array}$ & No & - & $\begin{array}{l}\text { Rusli et al. } \\
\text { (2019) }\end{array}$ \\
\hline & \multirow[t]{2}{*}{$0.3 \mu \mathrm{M}$} & $\begin{array}{l}\text { In vitro permeability assay using primary } \\
\text { porcine brain endothelial cells with or } \\
\text { without P-gp inhibitor valspodar } \\
\text { (PSC833; } 1 \mu \mathrm{M})\end{array}$ & $\begin{array}{l}\text { Increased apical to basal } \\
\text { permeability (blood to brain side) in } \\
\text { presence of valspodar }\end{array}$ & Yes (P-gp) & - & \multirow[t]{2}{*}{$\begin{array}{l}\text { Yusof et al. } \\
\text { (2019) }\end{array}$} \\
\hline & & $\begin{array}{l}\text { Brain extent study-combinatory } \\
\text { approach of in vivo } \\
\text { neuropharmacokinetic, in vitro drug } \\
\text { tissue binding and brain slice assays }\end{array}$ & $K_{\mathrm{p}, \mathrm{uu}, \text { brain }}<1$ indicating net efflux & Yes & & \\
\hline & $40 \mu \mathrm{g} / \mathrm{ml}$ & $\begin{array}{l}\text { In situ single pass intestinal perfusion in } \\
\text { small intestine of rats with or without } \\
\text { P-gp inhibitor azithromycin }(200 \mu \mathrm{g} / \mathrm{ml})\end{array}$ & $\begin{array}{l}\text { Permeability was unaltered in } \\
\text { presence of azithromycin }\end{array}$ & No & - & $\begin{array}{l}\text { Jabagabalan } \\
\text { et al. (2019) }\end{array}$ \\
\hline & - & $\begin{array}{l}\text { In vitro uptake assay of } \mathrm{P} \text {-gp substrate } \\
\text { calcein-AM in presence of mitragynine } \\
\text { at different concentrations }\end{array}$ & $\begin{array}{l}\text { Increased uptake of calcein-AM in } \\
\text { MDR-MDCKII cells in presence of } \\
\text { mitragynine dose-dependently } \\
\left(\mathrm{EC}_{50}=18.2 \mu \mathrm{M}\right)\end{array}$ & - & Yes (P-gp) & $\begin{array}{l}\text { Manda et al. } \\
(2014)\end{array}$ \\
\hline & $5 \mu \mathrm{M}$ & $\begin{array}{l}\text { In vitro permeability assay of P-gp } \\
\text { substrate rhodamine } 123 \text { across Caco- } \\
2 \text { cell monolayers with or without } \\
\text { mitragynine in basolateral to apical } \\
\text { (secretory) direction }\end{array}$ & $\begin{array}{l}\text { Reduced basolateral to apical } \\
\text { permeability of rhodamine } 123 \text { in } \\
\text { presence of mitragynine }\end{array}$ & - & Yes (P-gp) & $\begin{array}{l}\text { Meyer et al. } \\
(2015)\end{array}$ \\
\hline & $10 \mu \mathrm{M}$ & $\begin{array}{l}\text { In vitro permeability assay of P-gp } \\
\text { substrate digoxin across Caco- } 2 \text { cell } \\
\text { monolayers with or without mitragynine }\end{array}$ & $\begin{array}{l}\text { Reduced basolateral to apical } \\
\text { permeability of digoxin in presence } \\
\text { of mitragynine }\end{array}$ & - & Yes (P-gp) & $\begin{array}{l}\text { Rusli et al. } \\
\text { (2019) }\end{array}$ \\
\hline & $0.3 \mu \mathrm{M}$ & $\begin{array}{l}\text { In vitro permeability assay of P-gp } \\
\text { substrate digoxin across primary } \\
\text { porcine brain endothelial cell } \\
\text { monolayers with or without mitragynine } \\
\text { in apical to basolateral (absorptive) } \\
\text { direction }\end{array}$ & $\begin{array}{l}\text { Increased apical to basolateral } \\
\text { permeability of digoxin in presence } \\
\text { of mitragynine }\end{array}$ & - & Yes (P-gp) & $\begin{array}{l}\text { Yusof et al. } \\
(2019)\end{array}$ \\
\hline & $5,50,500 \mu \mathrm{M}$ & Human BCRP (hBCRP) ATPase activity & $\begin{array}{l}\text { Mitragynine stimulated hBCRP } \\
\text { ATPase at all concentrations tested, } \\
\text { and inihibited hBCRP ATPase at } \\
500 \mu \mathrm{M}\end{array}$ & Yes & $\begin{array}{l}\text { Possibly weak } \\
\text { inhibition due to } \\
\mathrm{IC}_{50} \text { value }\end{array}$ & $\begin{array}{l}\text { Wagmann et al. } \\
\text { (2018) }\end{array}$ \\
\hline & $5-2,500 \mu \mathrm{M}$ & Determination of $\mathrm{IC}_{50}$ & $\mathrm{IC}_{50}=359 \mu \mathrm{M}$ & & & \\
\hline \multirow[t]{4}{*}{$\begin{array}{l}\text { 7-hydroxy- } \\
\text { mitragynine }\end{array}$} & $5,10 \mu \mathrm{M}$ & $\begin{array}{l}\text { In vitro bidirectional permeability assay } \\
\text { using Caco- } 2 \text { and MDR-MDCKII cells }\end{array}$ & $\begin{array}{l}\text { No polarization of transport. Efflux } \\
\text { ratio }=1.2\end{array}$ & No & - & $\begin{array}{l}\text { Manda et al. } \\
(2014)\end{array}$ \\
\hline & $0.3 \mu \mathrm{M}$ & $\begin{array}{l}\text { In vitro bidirectional permeability assay } \\
\text { using primary porcine brain endothelial } \\
\text { cells }\end{array}$ & $\begin{array}{l}\text { Higher basolateral to apical (brain to } \\
\text { blood side) permeability. Efflux ratio } \\
=1.39\end{array}$ & Yes (P-gp) & - & $\begin{array}{l}\text { Yusof et al. } \\
\text { (2019) }\end{array}$ \\
\hline & $0.3 \mu \mathrm{M}$ & $\begin{array}{l}\text { In vitro permeability assay with or } \\
\text { without P-gp inhibitor valspodar } \\
\text { (PSC833; } 1 \mu \mathrm{M})\end{array}$ & $\begin{array}{l}\text { Increased apical to basolateral } \\
\text { permeability (blood to brain side) in } \\
\text { presence of valspodar }\end{array}$ & & & \\
\hline & - & $\begin{array}{l}\text { Brain extent study - combinatory } \\
\text { approach of in vivo } \\
\text { neuropharmacokinetic, in vitro drug } \\
\text { tissue binding and brain slice assays }\end{array}$ & $K_{\mathrm{p}, \mathrm{uu}, \mathrm{brain}}<1$ indicating net efflux & Yes & & \\
\hline
\end{tabular}


TABLE 4 | (Continued) Functional interactions of kratom alkaloids with efflux transporters.

\begin{tabular}{|c|c|c|c|c|c|c|}
\hline Alkaloid & $\begin{array}{l}\text { Concentration } \\
\text { tested }\end{array}$ & Methods & Findings & $\begin{array}{c}\text { Subjected } \\
\text { to } \\
\text { efflux }\end{array}$ & $\begin{array}{l}\text { Efflux } \\
\text { transporter } \\
\text { inhibition }\end{array}$ & References \\
\hline & - & $\begin{array}{l}\text { In vitro uptake assay of } \mathrm{P} \text {-gp substrate } \\
\text { calcein-AM in presence of } 7 \text { - } \\
\text { hydroxymitragynine at different } \\
\text { concentrations }\end{array}$ & $\begin{array}{l}\text { Increased uptake of calcein-AM in } \\
\text { MDR-MDCKII cells in presence of } 7 \text { - } \\
\text { hydroxymitragynine dose- } \\
\text { dependently }\left(\mathrm{EC}_{50}=32.4 \mu \mathrm{M}\right)\end{array}$ & - & Yes (P-gp) & $\begin{array}{l}\text { Manda et al. } \\
(2014)\end{array}$ \\
\hline & $0.3 \mu \mathrm{M}$ & $\begin{array}{l}\text { In vitro permeability assay of P-gp } \\
\text { substrate digoxin across primary } \\
\text { porcine brain endothelial cell } \\
\text { monolayers with or without } 7 \text { - } \\
\text { hydroxymitragynine in apical to } \\
\text { basolateral (absorptive) direction }\end{array}$ & $\begin{array}{l}\text { Increased apical to basolateral } \\
\text { permeability of digoxin in presence } \\
\text { of 7-hydroxymitragynine }\end{array}$ & - & Yes (P-gp) & $\begin{array}{l}\text { Yusof et al. } \\
\text { (2019) }\end{array}$ \\
\hline \multirow[t]{2}{*}{ Mitraphylline } & $5,10 \mu \mathrm{M}$ & $\begin{array}{l}\text { In vitro bidirectional permeability assay } \\
\text { using Caco- } 2 \text { and MDR-MDCKII cells }\end{array}$ & $\begin{array}{l}\text { Higher basolateral to apical } \\
\text { (secretory) permeability with efflux } \\
\text { ratio of } 3.3-6.6\end{array}$ & Yes & & $\begin{array}{l}\text { Manda et al. } \\
(2014)\end{array}$ \\
\hline & - & $\begin{array}{l}\text { In vitro uptake assay of } \mathrm{P} \text {-gp substrate } \\
\text { calcein-AM in presence of mitraphylline } \\
\text { at different concentrations }\end{array}$ & No effect on calcein-AM uptake & & No & $\begin{array}{l}\text { Manda et al. } \\
(2014)\end{array}$ \\
\hline
\end{tabular}

$10^{-6} \mathrm{~cm} / \mathrm{s}$ when tested at $5 \mu \mathrm{M}$, and $3.4 \times 10^{-6} \mathrm{~cm} / \mathrm{s}$ when tested at $10 \mu \mathrm{M}$ (Manda et al., 2014).

\subsection{Interactions With Membrane Transporters}

Physiological barriers not only act as a physical barrier which is contributed by the restrictive tight junctions, but also as metabolic and transport barriers to permeation of molecules (Abbott et al., 2006). The transport barrier is imposed by solute carrier (SLC) and ATP-binding cassette $(\mathrm{ABC})$ transporters, which function to either facilitate or impede transcellular permeability across the barriers. In drug discovery and development, prediction or determination of compounds' potential substrates for the $\mathrm{ABC}$ transporters particularly the P-glycoprotein (P-gp) is often considered. Efflux by the P-gp which has broad substrate specificity could affect the pharmacokinetics of a compound such as limiting intestinal absorption, impeding CNS penetration, and thus influencing drug delivery and targeting (Lin and Yamazaki, 2003; Miller, 2015). To overcome this, modulation of the P-gp function to reduce efflux, or alteration of the P-gp expression are some of the approaches being explored to improve drug delivery (Miller, 2015).

Evidence on mitragynine and 7-hydroxymitragynine P-gpmediated efflux are conflicting (Table 4). Lack of polarization in bidirectional transport measured in vitro indicated no potential efflux, and unaltered permeability in presence of P-gp inhibitors suggested that the alkaloids were not substrates of P-gp (Manda et al., 2014; Meyer et al., 2015; Jagabalan et al., 2019; Rusli et al., 2019). However, when the alkaloids were tested at submicromolar concentration, an increase in apical to basolateral permeability was observed in presence of the P-gp inhibitor, valspodar (PSC833), suggesting P-gp-mediated efflux (Yusof et al., 2019). The differences in concentrations used to test the alkaloids in the studies may explain the discrepancies of the findings, as higher concentrations can cause transporter saturation, and this, in turn, affects readouts of in vitro bidirectional permeability assay (Saaby and Brodin, 2017). On the other hand, P-gp-mediated efflux of mitraphylline was evident from Manda et al. study.

Previous studies are in agreement that mitragynine and 7hydroxymitragynine inhibited P-gp-mediated efflux of known substrates of the transporter (Table 4). The alkaloids dosedependently increased MDR-MDCK cell uptake of calcein-AM, with mitragynine and 7-hydroxymitragynine $\mathrm{EC}_{50}$ of 18.2 and $32.4 \mu \mathrm{M}$ respectively, comparable to the $\mathrm{P}$-gp inhibitor verapamil which shown $\mathrm{EC}_{50}$ of $22.3 \mu \mathrm{M}$ (Manda et al., 2014). In the Caco-2 model, mitragynine was demonstrated to reduce the permeability of rhodamine 123 and digoxin in the basolateral to the apical direction (secretory direction) at 5 and $10 \mu \mathrm{M}$ (Meyer et al., 2015; Rusli et al., 2019). We also found evidence for mitragynine and 7 hydroxymitragynine inhibition of $\mathrm{P}$-gp-mediated efflux of digoxin at a concentration of $0.3 \mu \mathrm{M}$, comparable to inhibition by valspodar (Yusof et al., 2019). The inhibition of P-gp-mediated efflux by kratom alkaloids needs careful considerations as this could potentially cause interactions with drugs that are substrates of the P-gp. Co-presence of the alkaloids and the drugs may lead to an increase in the drugs absorption and tissue distribution, and decrease elimination. While this could be a strategy for the drugs to reach sites of action, the non-specific inhibition of the P-gp in non-targeted tissues could contribute to cytotoxicity.

Another important $\mathrm{ABC}$ transporter which expression includes at the gastrointestinal tract and at the $\mathrm{BBB}$ is the breast cancer resistance protein (BCRP). At the human $\mathrm{BBB}$, the $\mathrm{BCRP}$ expression was found to be the most abundant among the $\mathrm{ABC}$ transporters, 1.34 fold higher than the P-gp expression; while the opposite was found for mice where the P-gp expression was 3.20 fold higher than the BCRP expression (Uchida et al., 2011). This need to be taken into consideration when extrapolating data from mice to human. The two transporters have been reported to work cooperatively in limiting the entry of chemotherapeutic drugs into the brain, and inhibition of 
one transporter can be compensated by the other (Agarwal et al., 2011). Based on human BCRP ATPase activity where the formation of ADP was quantified as an indicator for either stimulation or inhibition of the transporter in presence of test compounds, mitragynine was reported as a potential substrate of the BCRP and could inhibit the transporter function with an $\mathrm{IC}_{50}$ value of $359 \mu \mathrm{M}$ (Wagmann et al., 2018). Findings reported by Wagmann et al. (2018) and Yusof et al. (2019) provide evidence for mitragynine dual substrate of the P-gp and the BCRP.

Efflux of mitragynine and 7-hydroxymitragynine was also determined in the study of the alkaloids extent in the brain (Yusof et al., 2019). By using a combinatory approach of in vivo neuropharmacokinetic, in vitro drug tissue binding and brain slice assays to calculate total whole brain to plasma concentration ratio $\left(K_{\mathrm{p}, \text { brain }}\right)$, fraction of unbound alkaloids in plasma $\left(f_{\text {u,plasma }}\right)$, and volume of distribution of unbound alkaloids in the brain $\left(V_{\mathrm{u}, \text { brain }}\right)$ respectively, the extent of unbound alkaloids in the brain $\left(K_{\mathrm{p} \text {,uu,brain }}\right)$ yielded values of approximately 0.1 , which is below the value of unity (1), thus indicating efficient efflux of the alkaloids (Yusof et al., 2019).

Apart from interactions with the efflux transporters, mitragynine could also potentially be transported by influx transporters into the brain (Yusof et al., 2019). However, further investigations are needed to confirm this.

\subsection{Alteration of Barrier Function}

In vitro cell-based models of physiological barriers not only are great tools to investigate mechanisms of permeability but can also be used to determine the effects of exposure to compounds on the structure and function of the barriers. Exposure to mitragynine at 40 and $60 \mu \mathrm{M}$ for $48 \mathrm{~h}$ reduced the viability of human aortic endothelial cells, which was linked to an increase in intracellular reactive oxygen species (ROS) production, leading to caspase-3 activation, DNA fragmentation, and apoptosis (Matsunaga et al., 2017). The $\mathrm{LC}_{50}$ determined was $43.1 \mu \mathrm{M}$. The effect of mitragynine on the tight junction function of the human aortic endothelial cells was also investigated. The cells grown on semi-permeable inserts were exposed to mitragynine at $5 \mu \mathrm{M}$ either for a short, or long-term incubation of 5 days. The cells were also incubated with 10 and $20 \mu \mathrm{M}$ mitragynine for 5 days. The transendothelial electrical resistance was then measured as an indicator for tight junction integrity. Tight junction leakage to FITC-dextran with a molecular weight of approximately $150 \mathrm{kDa}$ was assessed. Findings from the study showed that the long-term exposure to mitragynine caused a decrease in tight junction tightness of the human aortic endothelial cells at all concentrations tested i.e. 5, 10, and $20 \mu \mathrm{M}$, which might contribute to leakage of the FITC-dextran at $20 \mu \mathrm{M}$ (Matsunaga et al., 2017). The decrease in tightness of the tight junction was not observed in cells pre-treated with ROS inhibitor, while ROS generators made it worse. This indicates the involvement of ROS in the disruption of tight junction integrity of the human aortic endothelial cells upon exposure to mitragynine (Matsunaga et al., 2017).

Mitragynine was found to alter the expression of the P-gp. The Caco-2 cells incubated with mitragynine at $0.1,1$, and $10 \mu \mathrm{M}$ for $72 \mathrm{~h}$ showed downregulation of mRNA and protein expression of the $\mathrm{P}$-gp in a concentration-dependent manner
(Rusli et al., 2019). The downregulation of expression correlates with reduced intensity of P-gp staining of the cells. The number of cells expressing P-gp was also reduced (Rusli et al., 2019).

Evidence of alteration of cellular barrier function by mitragynine in long-term exposure is concerning. In particular when the concentrations that affected the function falls within the range of mitragynine concentrations reported in human plasma, of which a range of $1.13-5.77 \mu \mathrm{M}$ was reported in a recent study by Vicknasingam et al. (2020). Future studies should look into other potential alterations to the barrier structure and function as part of safety evaluations.

\section{CONCLUSION}

Here, we have gathered and discussed physiological interactions of kratom alkaloids within the scope of interactions with drug-metabolizing enzymes and potential for drug-drug interactions, interactions with central nervous system receptors to relate with pharmacological actions, and interactions with cellular barriers of which are not limited to mechanisms of barrier permeability, but also effects of exposure to kratom alkaloids on the barrier function. Although the interactions with enzymes and the receptors may not be necessarily new in regards to kratom research, these areas have gained renewed interest among researchers in recent years due to the wealth of evidence on pharmacological actions of the alkaloids in preclinical studies, the rise of kratom use for self-treatment purposes, and the controversies surrounding the consumption of kratom. Meanwhile, interactions of kratom alkaloids with cellular barriers are largely unexplored.

Highlights from the discussion include the potential for clinically relevant drug-drug interaction due to modulation either in expression or function of drug-metabolizing enzymes, particularly the cytochrome P450 enzymes by the alkaloids. Secondly, kratom alkaloids have been known as atypical opioids stem from the discoveries of their opioids and non-opioids mechanistic. This multimechanistic property of the alkaloids could provide interesting avenues for the development of multi-targeted therapeutics for better efficacy and reduced side effects. As traditional uses generally involve consumption of a brewed drink, the mechanistic of the alkaloids as single compounds and in combination need to be delved deeper. Thirdly, cellular barriers imposed formidable hurdles in the development of therapeutics due to their protective nature and dynamic regulation of the tissue microenvironment. Therefore, a good understanding of the alkaloids' molecular traffic between physiological interfaces will aid future delivery strategies. As kratom alkaloids have been demonstrated to interact with membrane transporters particularly the efflux transporters, this could also imply the potential for drug-drug interaction with the transporter substrates. Taken together, interactions of kratom alkaloids with drug-metabolizing 
enzymes and cellular barriers not only affect their tissue distributions and the concentrations at target receptor sites to elicit functional responses, but also distributions, and functional responses of other drugs. As always, more work is needed to understand the physiological interactions of kratom alkaloids in the course of further development as potential therapeutics.

\section{AUTHOR CONTRIBUTIONS}

SY, JA, and NC conceptualized the content of the manuscript. SY, $\mathrm{JA}, \mathrm{NC}$, and $\mathrm{AH}$ wrote sections in the manuscript. All authors reviewed the manuscript and approved it for submission.

\section{REFERENCES}

Abbott, N. J., Patabendige, A. A., Dolman, D. E., Yusof, S. R., and Begley, D. J. (2010). Structure and Function of the Blood-Brain Barrier. Neurobiol. Dis. 37, 13-25. doi:10.1016/j.nbd.2009.07.030

Abbott, N. J., Rönnbäck, L., and Hansson, E. (2006). Astrocyte-endothelial Interactions at the Blood-Brain Barrier. Nat. Rev. Neurosci. 7, 41-53. doi:10.1038/nrn1824

Agarwal, S., Hartz, A. M., Elmquist, W. F., and Bauer, B. (2011). Breast Cancer Resistance Protein and P-Glycoprotein in Brain Cancer: Two Gatekeepers Team up. Curr. Pharm. Des. 17, 2793-2802. doi:10.2174/138161211797440186

Basiliere, S., and Kerrigan, S. (2020b). CYP450-mediated Metabolism of Mitragynine and Investigation of Metabolites in Human Urine. J. Anal. Toxicol. 44, 301-313. doi:10.1093/jat/bkz108

Basiliere, S., and Kerrigan, S. (2020a). Identification of Metabolites and Potential Biomarkers of Kratom in Urine. J. Chromatogr. B Analyt Technol. Biomed. Life Sci. 1140, 121971. doi:10.1016/j.jchromb.2020.121971

Beaulieu, J. M., and Gainetdinov, R. R. (2011). The Physiology, Signaling, and Pharmacology of Dopamine Receptors. Pharmacol. Rev. 63, 182-217. doi:10.1124/pr.110.002642

Beliveau, V., Ganz, M., Feng, L., Ozenne, B., Højgaard, L., Fisher, P. M., et al. (2017). A High-Resolution In Vivo Atlas of the Human Brain's Serotonin System. J. Neurosci. 37, 120-128. doi:10.1523/jneurosci.2830-16.2016

Bibi, Z. (2008). Role of Cytochrome P450 in Drug Interactions. Nutr. Metab. (Lond) 5, 27. doi:10.1186/1743-7075-5-27

Boyer, E. W., Babu, K. M., Adkins, J. E., McCurdy, C. R., and Halpern, J. H. (2008). Self-treatment of Opioid Withdrawal Using Kratom (Mitragynia Speciosa Korth). Addiction 103, 1048-1050. doi:10.1111/j.1360-0443.2008.02209.x

Burkill, I. H., and Haniff, M. (1930). "Malay Village Medicine," in the Garden's Bulletin, Straits Settlement, 6. Singapore: Botanic Gardens, 6-10.

Burkill, I. H. (1935). A Dictionary of the Economic Products of the Malay Peninsula, 2. London: Crown Agents for the Colonies, 1506-1508.

Carpenter, J. M., Criddle, C. A., Craig, H. K., Ali, Z., Zhang, Z., Khan, I. A., et al. (2016). Comparative Effects of Mitragyna Speciosa Extract, Mitragynine, and Opioid Agonists on Thermal Nociception in Rats. Fitoterapia 109, 87-90. doi:10.1016/j.fitote.2015.12.001

Chear, N. J., León, F., Sharma, A., Kanumuri, S. R. R., Zwolinski, G., Abboud, K. A., et al. (2021). Exploring the Chemistry of Alkaloids from Malaysian Mitragyna Speciosa (Kratom) and the Role of Oxindoles on Human Opioid Receptors. J. Nat. Prod. 84, 1034-1043. doi:10.1021/acs.jnatprod.0c01055

Chelakkot, C., Ghim, J., and Ryu, S. H. (2018). Mechanisms Regulating Intestinal Barrier Integrity and its Pathological Implications. Exp. Mol. Med. 50, 103-109. doi:10.1038/s12276-018-0126-x

Deodhar, M., Al Rihani, S. B., Arwood, M. J., Darakjian, L., Dow, P., Turgeon, J., et al. (2020). Mechanisms of CYP450 Inhibition: Understanding Drug-Drug Interactions Due to Mechanism-Based Inhibition in Clinical Practice. Pharmaceutics 12, 846-864. doi:10.3390/pharmaceutics12090846

\section{FUNDING}

Research projects conducted by the authors on kratom alkaloids are funded by the Ministry of Higher Education Malaysia under Fundamental Research Grant Scheme with project codes: FRGS/1/2019/STG05/USM/02/1 and FRGS/1/ 2020/STG01/USM/02/10, and Universiti Sains Malaysia Short Term Grant (304/CDADAH/6315457).

\section{ACKNOWLEDGMENTS}

Acknowledgement also goes to HICoE program (311.CDADAH.4401009).

Di, L. (2014). The Role of Drug Metabolizing Enzymes in Clearance. Expert Opin. Drug Metab. Toxicol. 10, 379-393. doi:10.1517/17425255.2014.876006

Ellis, C. R., Racz, R., Kruhlak, N. L., Kim, M. T., Zakharov, A. V., Southall, N., et al. (2020). Evaluating Kratom Alkaloids Using PHASE. PLoS One 15, e0229646. doi:10.1371/journal.pone.0229646

European Medicine Agency (EMA) (2012). In Guideline on the Investigation of Drug Interactions Committee for Human Medicinal Products (London: European Medicines Agency).

Food and Drug Administration Centre for Drug Evaluation and Research (2020). In Vitro Drug Interaction Studies - Cytochrome P450 Enzyme- and Transporter-Mediated Drug Interactions Guidance for Industry (Silver Spring, MD: U. S. Food and Drug Administration).

Foss, J. D., Nayak, S. U., Tallarida, C. S., Farkas, D. J., Ward, S. J., and Rawls, S. M. (2020). Mitragynine, Bioactive Alkaloid of Kratom, Reduces ChemotherapyInduced Neuropathic Pain in Rats through a-adrenoceptor Mechanism. Drug Alcohol Depend 209, 107946. doi:10.1016/j.drugalcdep.2020.107946

Gershman, K., Timm, K., Frank, M., Lampi, L., Melamed, J., Gerona, R., et al. (2019). Deaths in Colorado Attributed to Kratom. N. Engl. J. Med. 380, 97-98. doi:10.1056/NEJMc1811055

Grundmann, O. (2017). Patterns of Kratom Use and Health Impact in the USResults from an Online Survey. Drug Alcohol Depend 176, 63-70. doi:10.1016/ j.drugalcdep.2017.03.007

Hanapi, N. A., Ismail, S., and Mansor, S. M. (2013). Inhibitory Effect of Mitragynine on Human Cytochrome P450 Enzyme Activities. Pharmacognosy Res. 5, 241-246. doi:10.4103/0974-8490.118806

Hassan, R., Pike See, C., Sreenivasan, S., Mansor, S. M., Müller, C. P., and Hassan, Z. (2020). Mitragynine Attenuates Morphine Withdrawal Effects in Rats-A Comparison with Methadone and Buprenorphine. Front. Psychiatry 11, 411. doi:10.3389/fpsyt.2020.00411

Haupt, L. J., Kazmi, F., Ogilvie, B. W., Buckley, D. B., Smith, B. D., Leatherman, S., et al. (2015). The Reliability of Estimating Ki Values for Direct, Reversible Inhibition of Cytochrome P450 Enzymes from Corresponding IC50 Values: A Retrospective Analysis of 343 Experiments. Drug Metab. Dispos. 43, 1744-1750. doi:10.1124/dmd.115.066597

Hazim, A. I., Ramanathan, S., Parthasarathy, S., Muzaimi, M., and Mansor, S. M. (2014). Anxiolytic-like Effects of Mitragynine in the Open-Field and Elevated Plus-Maze Tests in Rats. J. Physiol. Sci. 64, 161-169. doi:10.1007/s12576-0140304-0

Helms, H. C., Abbott, N. J., Burek, M., Cecchelli, R., Couraud, P. O., Deli, M. A., et al. (2016). In Vitro Models of the Blood-Brain Barrier: An Overview of Commonly Used Brain Endothelial Cell Culture Models and Guidelines for Their Use. J. Cereb. Blood Flow. Metab. 36, 862-890. doi:10.1177/ $0271678 X 16630991$

Holanda, V. A. D., Oliveira, M. C., Souza, L. S., Lobão-Soares, B., André, E., Da Silva Junior, E. D., et al. (2019). Dopamine D1 and D2 Receptors Mediate Neuropeptide S-Induced Antinociception in the Mouse Formalin Test. Eur. J. Pharmacol. 859, 172557. doi:10.1016/j.ejphar.2019.172557

Hoyer, D., Clarke, D. E., Fozard, J. R., Hartig, P. R., Martin, G. R., Mylecharane, E. J., et al. (1994). International Union of Pharmacology 
Classification of Receptors for 5-hydroxytryptamine (Serotonin). Pharmacol. Rev. 46, 157-203.

Innok, W., Hiranrat, A., Chana, N., Rungrotmongkol, T., and Kongsune, P. (2021). In Silico and In Vitro Anti-AChE Activity Investigations of Constituents from Mytragyna Speciosa for Alzheimer's Disease Treatment. J. Comput. Aided Mol. Des. 35, 325-336. doi:10.1007/s10822-020-00372-4

Jagabalan, J. D. Y., Murugaiyah, V., Zainal, H., Mansor, S. M., and Ramanathan, S. (2019). Intestinal Permeability of Mitragynine in Rats Using In Situ Absorption Model. J. Asian Nat. Prod. Res. 21, 351-363. doi:10.1080/ 10286020.2018 .1461088

Jeong, E. J., Liu, Y., Lin, H., and Hu, M. (2004). "In Situ Single-Pass Perfused Rat Intestinal Model for Absorption and Metabolism," in Methods in Pharmacology and Toxicology. Editors Z. Yan and G. W. Caldwell (Totowa, NJ: Humana Press), 65-76. doi:10.1385/1-59259-800-5:065

Kamble, S. H., Sharma, A., King, T. I., Berthold, E. C., León, F., Meyer, P. K. L., et al. (2020). Exploration of Cytochrome P450 Inhibition Mediated Drug-Drug Interaction Potential of Kratom Alkaloids. Toxicol. Lett. 319, 148-154. doi:10.1016/.j.toxlet.2019.11.005

Kamble, S. H., Sharma, A., King, T. I., León, F., McCurdy, C. R., and Avery, B. A. (2019). Metabolite Profiling and Identification of Enzymes Responsible for the Metabolism of Mitragynine, the Major Alkaloid of Mitragyna Speciosa (Kratom). Xenobiotica 49, 1279-1288. doi:10.1080/00498254.2018.1552819

Kruegel, A. C., Gassaway, M. M., Kapoor, A., Váradi, A., Majumdar, S., Filizola, M., et al. (2016). Synthetic and Receptor Signaling Explorations of the Mitragyna Alkaloids: Mitragynine as an Atypical Molecular Framework for Opioid Receptor Modulators. J. Am. Chem. Soc. 138, 6754-6764. doi:10.1021/ jacs.6b00360

Lim, E. L., Seah, T. C., Koe, X. F., Wahab, H. A., Adenan, M. I., Jamil, M. F., et al. (2013). In Vitro Evaluation of Cytochrome P450 Induction and the Inhibition Potential of Mitragynine, a Stimulant Alkaloid. Toxicol. Vitro 27, 812-824. doi:10.1016/j.tiv.2012.12.014

Lin, J. H., and Yamazaki, M. (2003). Role of P-Glycoprotein in Pharmacokinetics: Clinical Implications. Clin. Pharmacokinet. 42, 59-98. doi:10.2165/00003088200342010-00003

Lynch, T., and Price, A. (2007). The Effect of Cytochrome P450 Metabolism on Drug Response, Interactions, and Adverse Effects. Am. Fam. Physician 76, 391-396.

Manda, V. K., Avula, B., Ali, Z., Khan, I. A., Walker, L. A., and Khan, S. I. (2014). Evaluation of In Vitro Absorption, Distribution, Metabolism, and Excretion (ADME) Properties of Mitragynine, 7-Hydroxymitragynine, and Mitraphylline. Planta Med. 80, 568-576. doi:10.1055/s-0034-1368444

Matsumoto, K., Mizowaki, M., Suchitra, T., Murakami, Y., Takayama, H., Sakai, S., et al. (1996b). Central Antinociceptive Effects of Mitragynine in Mice: Contribution of Descending Noradrenergic and Serotonergic Systems. Eur. J. Pharmacol. 317, 75-81. doi:10.1016/s0014-2999(96)00714-5

Matsumoto, K., Mizowaki, M., Suchitra, T., Takayama, H., Sakai, S., Aimi, N., et al. (1996a). Antinociceptive Action of Mitragynine in Mice: Evidence for the Involvement of Supraspinal Opioid Receptors. Life Sci. 59, 1149-1155. doi:10.1016/0024-3205(96)00432-8

Matsumoto, K., Mizowaki, M., Takayama, H., Sakai, S., Aimi, N., and Watanabe, H. (1997). Suppressive Effect of Mitragynine on the 5-Methoxy-N,NDimethyltryptamine-Induced Head-Twitch Response in Mice. Pharmacol. Biochem. Behav. 57, 319-323. doi:10.1016/s0091-3057(96)00314-0

Matsunaga, T., Morikawa, Y., Kamase, K., Horinouchi, M., Sasajima, Y., Suenami, K., et al. (2017). Enhancement of Endothelial Barrier Permeability by Mitragynine. Biol. Pharm. Bull. 40, 1779-1783. doi:10.1248/bpb.b17-00117

Meyer, M. R., Wagmann, L., Schneider-Daum, N., Loretz, B., de Souza Carvalho, C., Lehr, C. M., et al. (2015). P-glycoprotein Interactions of Novel Psychoactive Substances - Stimulation of ATP Consumption and Transport across Caco-2 Monolayers. Biochem. Pharmacol. 94, 220-226. doi:10.1016/j.bcp.2015.01.008

Miller, D. S. (2015). Regulation of ABC Transporters Blood-Brain Barrier: the Good, the Bad, and the Ugly. Adv. Cancer Res. 125, 43-70. doi:10.1016/ bs.acr.2014.10.002

Mishra, A., Singh, S., and Shukla, S. (2018). Physiological and Functional Basis of Dopamine Receptors and Their Role in Neurogenesis: Possible Implication for Parkinson's Disease. J. Exp. Neurosci. 12, 1179069518779829. doi:10.1177/ 1179069518779829
Nichols, D. E., and Nichols, C. D. (2008). Serotonin Receptors. Chem. Rev. 108, 1614-1641. doi:10.1021/cr078224o

Obach, R. S., Walsky, R. L., Venkatakrishnan, K., Gaman, E. A., Houston, J. B., and Tremaine, L. M. (2006). The Utility of In Vitro Cytochrome P450 Inhibition Data in the Prediction of Drug-Drug Interactions. J. Pharmacol. Exp. Ther. 316, 336-348. doi:10.1124/jpet.105.093229

Obeng, S., Kamble, S. H., Reeves, M. E., Restrepo, L. F., Patel, A., Behnke, M., et al. (2020). Investigation of the Adrenergic and Opioid Binding Affinities, Metabolic Stability, Plasma Protein Binding Properties, and Functional Effects of Selected Indole-Based Kratom Alkaloids. J. Med. Chem. 63, 433-439. doi:10.1021/acs.jmedchem.9b01465

Obeng, S., León, F., Patel, A., Restrepo, L., Gamez-Jimenez, L., Zuarth Gonzalez, J., et al. (2021). Serotonin 5-HT 1A Receptor Activity of Kratom Alkaloids Mitragynine, Paynantheine, and Speciogynine. FASEB j. 35. doi:10.1096/ fasebj.2021.35.S1.04764

Philipp, A. A., Wissenbach, D. K., Weber, A. A., Zapp, J., and Maurer, H. H. (2011a). Metabolism Studies of the Kratom Alkaloid Speciociliatine, a Diastereomer of the Main Alkaloid Mitragynine, in Rat and Human Urine Using Liquid Chromatography-Linear Ion Trap Mass Spectrometry. Anal. Bioanal. Chem. 399, 2747-2753. doi:10.1007/s00216-011-4660-9

Philipp, A. A., Wissenbach, D. K., Weber, A. A., Zapp, J., and Maurer, H. H. (2011b). Metabolism Studies of the Kratom Alkaloids Mitraciliatine and Isopaynantheine, Diastereomers of the Main Alkaloids Mitragynine and Paynantheine, in Rat and Human Urine Using Liquid ChromatographyLinear Ion Trap-Mass Spectrometry. J. Chromatogr. B Analyt. Technol. Biomed. Life Sci. 879, 1049-1055. doi:10.1016/j.jchromb.2011.03.005

Philipp, A. A., Wissenbach, D. K., Weber, A. A., Zapp, J., and Maurer, H. H. (2010b). Phase I and II Metabolites of Speciogynine, a Diastereomer of the Main Kratom Alkaloid Mitragynine, Identified in Rat and Human Urine by Liquid Chromatography Coupled to Low- and High-Resolution Linear Ion Trap Mass Spectrometry. J. Mass. Spectrom. 45, 1344-1357. doi:10.1002/jms.1848

Philipp, A. A., Wissenbach, D. K., Weber, A. A., Zapp, J., Zoerntlein, S. W., Kanogsunthornrat, J., et al. (2010a). Use of Liquid Chromatography Coupled to Low- and High-Resolution Linear Ion Trap Mass Spectrometry for Studying the Metabolism of Paynantheine, an Alkaloid of the Herbal Drug Kratom in Rat and Human Urine. Anal. Bioanal. Chem. 396, 2379-2391. doi:10.1007/s00216009-3239-1

Philipp, A. A., Wissenbach, D. K., Zoerntlein, S. W., Klein, O. N., Kanogsunthornrat, J., and Maurer, H. H. (2009). Studies on the Metabolism of Mitragynine, the Main Alkaloid of the Herbal Drug Kratom, in Rat and Human Urine Using Liquid Chromatography-Linear Ion Trap Mass Spectrometry. J. Mass. Spectrom. 44, 1249-1261. doi:10.1002/jms.1607

Ramanathan, S., León, F., Chear, N. J. Y., Yusof, S. R., Murugaiyah, V., McMahon, L. R., et al. (2021). "Kratom (Mitragyna Speciosa Korth.): A Description on the Ethnobotany, Alkaloid Chemistry, and Neuropharmacology," in Studies in Natural Products Chemistry. Editor A. Rahman (Elsevier), 69, 195-225. doi:10.1016/b978-0-12-819487-4.00003-3

Rusli, N., Amanah, A., Kaur, G., Adenan, M. I., Sulaiman, S. F., Wahab, H. A., et al. (2019). The Inhibitory Effects of Mitragynine on P-Glycoprotein In Vitro. Naunyn Schmiedebergs Arch. Pharmacol. 392, 481-496. doi:10.1007/s00210-018-01605-y

Saaby, L., and Brodin, B. (2017). A Critical View on In Vitro Analysis of P-Glycoprotein (P-Gp) Transport Kinetics. J. Pharm. Sci. 106, 2257-2264. doi:10.1016/j.xphs.2017.04.022

Sabetghadam, A., Ramanathan, S., and Mansor, S. M. (2010). The Evaluation of Antinociceptive Activity of Alkaloid, Methanolic, and Aqueous Extracts of Malaysian Mitragyna Speciosa Korth Leaves in Rats. Pharmacognosy Res. 2, 181-185. doi:10.4103/0974-8490.65514

Schaffenburg, W. C., Lockshin, B. N., and Deklotz, C. M. C. (2021). "Polymorphisms," in Comprehensive Dermatologic Drug Therapy. Editor S. E. Wolverton. Fourth Edition (Elsevier), 21-33. doi:10.1016/b978-0-323-61211-1.00003-6

Shaik Mossadeq, W. M., Sulaiman, M. R., Tengku Mohamad, T. A., Chiong, H. S., Zakaria, Z. A., Jabit, M. L., et al. (2009). Anti-inflammatory and Antinociceptive Effects of Mitragyna Speciosa Korth Methanolic Extract. Med. Princ. Pract. 18, 378-384. doi:10.1159/000226292

Shapiro, L. E., and Shear, N. H. (2001). Drug Interactions/P450. Curr. Probl. Dermatol. 13, 141-152. doi:10.1016/S1040-0486(01)70007-5 
Singh, D., Narayanan, S., Müller, C. P., Swogger, M. T., Chear, N. J. Y., Dzulkapli, E. B., et al. (2019). Motives for Using Kratom (Mitragyna Speciosa Korth.) Among Regular Users in Malaysia. J. Ethnopharmacol. 233, 34-40. doi:10.1016/ j.jep.2018.12.038

Singh, D., Yeou Chear, N. J., Narayanan, S., Leon, F., Sharma, A., Mccurdy, C. R., et al. (2020a). Patterns and Reasons for Kratom (Mitragyna Speciosa) Use Among Current and Former Opioid Poly-Drug Users. J. Ethnopharmacol. 249, 112462. doi:10.1016/j.jep.2019.112462

Singh, D., Grundmann, O., Murugaiyah, V., Rahim, A. B. M., Chawarski, M., and Balasingam, V. (2020b). Improved Sexual Functioning of Long-Term Daily Users of Mitragyna Speciosa (Korth.). J. Herbal Med. 19, 100293. doi:10.1016/ j.hermed.2019.100293

Smith, K. E., and Lawson, T. (2017). Prevalence and Motivations for Kratom Use in a Sample of Substance Users Enrolled in a Residential Treatment Program. Drug Alcohol Depend 180, 340-348. doi:10.1016/ j.drugalcdep.2017.08.034

Smith, K. E., Rogers, J. M., Schriefer, D., and Grundmann, O. (2021). Therapeutic Benefit with Caveats?: Analyzing Social Media Data to Understand the Complexities of Kratom Use. Drug Alcohol Depend 226, 108879. doi:10.1016/j.drugalcdep.2021.108879

Sweeney, M. D., Zhao, Z., Montagne, A., Nelson, A. R., and Zlokovic, B. V. (2019). Blood-brain Barrier: from Physiology to Disease and Back. Physiol. Rev. 99, 21-78. doi:10.1152/physrev.00050.2017

Takayama, H., Ishikawa, H., Kurihara, M., Kitajima, M., Aimi, N., Ponglux, D., et al. (2002). Studies on the Synthesis and Opioid Agonistic Activities of Mitragynine-Related Indole Alkaloids: Discovery of Opioid Agonists Structurally Different from Other Opioid Ligands. J. Med. Chem. 45, 1949-1956. doi:10.1021/jm010576e

Tanna, R. S., Tian, D. D., Cech, N. B., Oberlies, N. H., Rettie, A. E., Thummel, K. E., et al. (2021). Refined Prediction of Pharmacokinetic Kratom-Drug Interactions: Time-dependent Inhibition Considerations. J. Pharmacol. Exp. Ther. 376, 64-73. doi:10.1124/jpet.120.000270

Templeton, I. E., Chen, Y., Mao, J., Lin, J., Yu, H., Peters, S., et al. (2016). Quantitative Prediction of Drug-Drug Interactions Involving Inhibitory Metabolites in Drug Development: How Can Physiologically Based Pharmacokinetic Modeling Help? CPT Pharmacometrics Syst. Pharmacol. 5, 505-515. doi:10.1002/psp4.12110

Tod, M., Pierrillas, P. B., Bourguignon, L., and Goutelle, S. (2016). Comparison of the Static In Vivo Approach to a Physiologically Based Pharmacokinetic Approach for Metabolic Drug-Drug Interactions Prediction. Int. J. Pharmacokinet. 1, 25-34. doi:10.4155/ipk.16.2

Todd, D. A., Kellogg, J. J., Wallace, E. D., Khin, M., Flores-Bocanegra, L., Tanna, R. S., et al. (2020). Chemical Composition and Biological Effects of Kratom (Mitragyna Speciosa): In Vitro Studies with Implications for Efficacy and Drug Interactions. Sci. Rep. 10, 19158. doi:10.1038/s41598020-76119-w

Uchida, Y., Ohtsuki, S., Katsukura, Y., Ikeda, C., Suzuki, T., Kamiie, J., et al. (2011). Quantitative Targeted Absolute Proteomics of Human Blood-Brain Barrier Transporters and Receptors. J. Neurochem. 117, 333-345. doi:10.1111/j.14714159.2011.07208.x

Utar, Z., Majid, M. I., Adenan, M. I., Jamil, M. F., and Lan, T. M. (2011). Mitragynine Inhibits the COX-2 mRNA Expression and Prostaglandin $\mathrm{E}_{2}$
Production Induced by Lipopolysaccharide in RAW264.7 Macrophage Cells. J. Ethnopharmacol. 136, 75-82. doi:10.1016/j.jep.2011.04.011

Vancamelbeke, M., and Vermeire, S. (2018). The Intestinal Barrier: a Fundamental Role in Health and Disease. Expert Rev. Gastroenterol. Hepatol. 11, 821-834. doi:10.1080/17474124.2017.1343143

Vicknasingam, B., Chooi, W. T., Rahim, A. A., Ramachandram, D., Singh, D., Ramanathan, S., et al. (2020). Kratom and Pain Tolerance: a Randomized, Placebo-Controlled, Double-Blind Study. Yale J. Biol. Med. 93, 229-238.

Vijeepallam, K., Pandy, V., Kunasegaran, T., Murugan, D. D., and Naidu, M. (2016). Mitragyna Speciosa Leaf Extract Exhibits Antipsychotic-like Effect with the Potential to Alleviate Positive and Negative Symptoms of Psychosis in Mice. Front. Pharmacol. 7, 464. doi:10.3389/fphar.2016.00464

Volpe, D. A. (2020). Advances in Cell-Based Permeability Assays to Screen Drugs for Intestinal Absorption. Expert Opin. Drug Discov. 15, 539-549. doi:10.1080/ 17460441.2020 .1735347

Wagmann, L., Maurer, H. H., and Meyer, M. R. (2018). Inhibition and Stimulation of the Human Breast Cancer Resistance Protein as In Vitro Predictor of DrugDrug Interactions of Drugs of Abuse. Arch. Toxicol. 92, 2875-2884. doi:10.1007/s00204-018-2276-y

Wienkers, L. C., and Heath, T. G. (2005). Predicting In Vivo Drug Interactions from In Vitro Drug Discovery Data. Nat. Rev. Drug Discov. 4, 825-833. doi: $10.1038 / \operatorname{nrd} 1851$

Williams, R. S., and Nikitin, D. (2020). The Internet Market for Kratom, an Opioid Alternative and Variably Legal Recreational Drug. Int. J. Drug Pol. 78, 102715. doi:10.1016/j.drugpo.2020.102715

Yung-Chi, C., and Prusoff, W. H. (1973). Relationship between the Inhibition Constant (KI) and the Concentration of Inhibitor Which Causes 50 Per Cent Inhibition (I50) of an Enzymatic Reaction. Biochem. Pharmacol. 22, 3099-3108. doi:10.1016/0006-2952(73)90196-2

Yusof, S. R., Mohd Uzid, M., Teh, E. H., Hanapi, N. A., Mohideen, M., Mohamad Arshad, A. S., et al. (2019). Rate and Extent of Mitragynine and 7hydroxymitragynine Blood-Brain Barrier Transport and Their Intra-brain Distribution: the Missing Link in Pharmacodynamic Studies. Addict. Biol. 24, 935-945. doi:10.1111/adb.12661

Conflict of Interest: The authors declare that the research was conducted in the absence of any commercial or financial relationships that could be construed as a potential conflict of interest.

Publisher's Note: All claims expressed in this article are solely those of the authors and do not necessarily represent those of their affiliated organizations, or those of the publisher, the editors, and the reviewers. Any product that may be evaluated in this article or claim that may be made by its manufacturer is not guaranteed or endorsed by the publisher.

Copyright $\odot 2021$ Hanapi, Chear, Azizi and Yusof. This is an open-access article distributed under the terms of the Creative Commons Attribution License (CC BY). The use, distribution or reproduction in other forums is permitted, provided the original author(s) and the copyright owner(s) are credited and that the original publication in this journal is cited, in accordance with accepted academic practice. No use, distribution or reproduction is permitted which does not comply with these terms. 